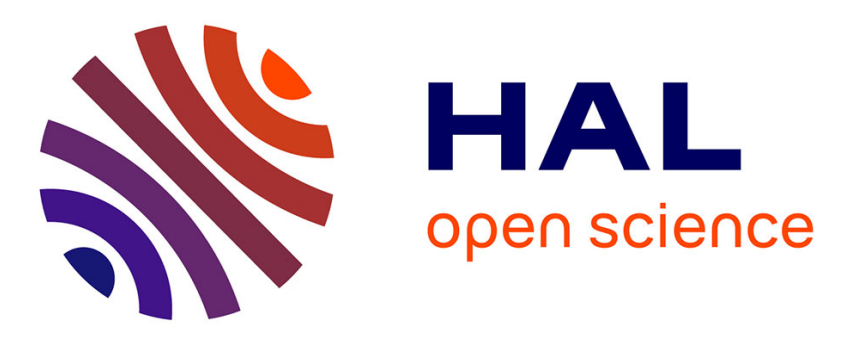

\title{
The influence of bioturbation and water column oxygenation on nutrient recycling in reservoir sediments
}

Edwige Gautreau, Laurence Volatier, Géraldine Nogaro, Emma Gouze, Florian Mermillod-Blondin

\section{- To cite this version:}

Edwige Gautreau, Laurence Volatier, Géraldine Nogaro, Emma Gouze, Florian Mermillod-Blondin. The influence of bioturbation and water column oxygenation on nutrient recycling in reservoir sediments. Hydrobiologia, 2020, 847 (4), pp.1027-1040. 10.1007/s10750-019-04166-0 . hal-02515796

\section{HAL Id: hal-02515796 \\ https://univ-lyon1.hal.science/hal-02515796}

Submitted on 10 Dec 2020

HAL is a multi-disciplinary open access archive for the deposit and dissemination of scientific research documents, whether they are published or not. The documents may come from teaching and research institutions in France or abroad, or from public or private research centers.
L'archive ouverte pluridisciplinaire HAL, est destinée au dépôt et à la diffusion de documents scientifiques de niveau recherche, publiés ou non, émanant des établissements d'enseignement et de recherche français ou étrangers, des laboratoires publics ou privés. 
2 Influences of bioturbation and water column oxygenation on nutrient recycling from reservoir sediments

3

4

5

6

7

Abstract

13

Sediments act as sinks of nutrients in aquatic ecosystems but may also act as nutrient sources, leading to eutrophication of lakes and reservoirs during the warm season of the year. In this context, internal recycling of nutrients from sediments can be largely modulated by abiotic (e.g., redox conditions) and biotic (e.g., activity of

Authors

Edwige Gautreau ${ }^{1,2, *}, \quad$ Laurence $\quad$ Volatier $^{1} \quad$ (laurence.volatier@entpe.fr), Géraldine Nogaro ${ }^{2}$ (geraldine.nogaro@edf.fr),Emma Gouze² (emma.gouze@edf.fr), Florian Mermillod-Blondin¹ (florian.mermillodblondin@univ-lyon1.fr)

*Corresponding author: edwige.gautreau@univ-lyon1.fr

${ }^{1}$ Univ Lyon, Université Claude Bernard Lyon 1, CNRS, ENTPE, UMR5023, Écologie des Hydrosystèmes Naturels et Anthropisés, Villeurbanne, F-69622, France

${ }^{2}$ EDF R\&D, Laboratoire National d'Hydraulique et Environnement, 6 quai Watier, BP49, 78401 Chatou benthic organisms) factors occurring at the water-sediment interface. The present study aimed at quantifying the effects of these factors (water column oxygenation and bioturbation by two bioturbating species - the tubificid worm Tubifex tubifex and insect larvae of Chironomus plumosus) on benthic fluxes of nitrogen (N), phosphorus (P) and silicon ( $\mathrm{Si}$ ) from reservoir water-sediment interface. An experimental approach based on the reconstitution of the water-sediment interface in mesocosms has been developed in the laboratory to test three fauna conditions (no fauna, presence of worms, and presence of chironomids) and three conditions of water column oxygenation (constant aerobic conditions, fluctuations of oxygen concentrations and constant anaerobic conditions). The larvae

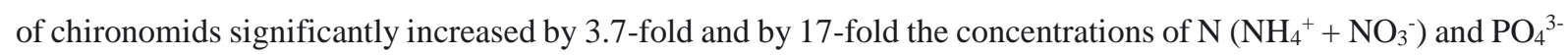
released from sediments, respectively. In comparison, tubificid worms had lower influences on these released nutrients ( $\mathrm{x} 2$ for $\mathrm{N}$ and $\mathrm{x} 3$ for $\mathrm{PO}_{4}{ }^{3-}$ in comparison with the control treatment without fauna). These contrasted effects of chironomids and tubificid worms on nutrient fluxes were related to their different bioturbation activities in sediments. Chironomid larvae increased water-sediment exchanges by actively ventilating their U-shaped 
burrows whereas tubificid worms produced deep galleries but they did not ventilate them to the same extent as chironomid burrows. Anaerobic conditions increased by 56 -fold $\mathrm{N}$ fluxes and by 102 -fold $\mathrm{PO}_{4}{ }^{3-}$ fluxes in comparison with the aerobic treatment. While anaerobic conditions could produce higher stimulation of $\mathrm{N}$ fluxes than bioturbation process, oxic-anoxic shift was also a stronger regulator of $\mathrm{P}$ fluxes than benthic fauna. Overall, bioturbating fauna and occurrence of anoxic conditions at the water-sediment interface should not be neglected in model assessing the role of sediments on nutrient dynamics in lakes and reservoirs during the season favorable to

34 algal blooms.

Key words

water-sediment interface, aerobic/anaerobic conditions, chironomid larvae, tubificid worms, fauna activity, nitrogen, phosphorus

Acknowledgments

The authors thank the ANRT (Association Nationale Recherche Technologie) and EDF (Electricité de France) for

41 Edwige Gautreau's Ph.D. grant (convention bourse CIFRE- EDF: $n^{\circ}$ 0733/2016). This study was funded by a 42 partnership EDF-CNRS (CNRS n $\left.{ }^{\circ} 49389\right)$ and Lyon Metropole within the framework of Sedaqua Platform 43 (Contrat Plan Etat Région). We also thank Félix Vallier, Athos Environnement (Antoine Thouvenot, David Foltier 44 and Benjamin Legrand), Pierre Rossignol, Laurent Simon, Michel Lafont, and Pierre Marmonier for their support and advices during field and laboratory works. 
The increasing anthropogenic discharge of nutrients is the primary cause of eutrophication in aquatic ecosystems.

This phenomenon is predominantly observed in aquatic systems such as lakes and reservoirs (Vitousek et al., 1997; Smith, 2003; Galloway et al., 2004). Indeed, reservoirs participate to more than 50\% of the sediment retention in drainage basins around the world (4-5 gigatons/year, Vörösmarty et al., 2003), leading to a massive accumulation of sediment-associated nutrients (nitrogen $\mathrm{N}$ and phosphorus $\mathrm{P}$ ).

During the warm season of the year, the eutrophication of aquatic ecosystems leads to algal blooms, especially cyanobacteria blooms resulting from oxygen depletion in ecosystems (Schindler, 1974; Findlay \& Kasian, 1987), which can lead to effects on fishes and macroinvertebrates (i.e. reduction of populations, Breitburg et al., 2009). For example, Foley et al. (2012) reported decreasing dissolved oxygen (DO) concentration with eutrophication in a lake monitored during more than 40 years. Consequently, eutrophication significantly impacts the human activities linked to reservoirs (e.g. drinking purposes, fishing) and eutrophic aquatic ecosystems have difficulties to meet EU Water Framework Directive (WFD 2000/60/EC ; European Council, 2000) requirements, which have to reach the good ecological status by 2027 for all surface waters.

In reservoirs, excessive nutrient loadings leading to the eutrophication of the water column have 2 origins: external (tributaries, atmospheric deposition, surface run-off, groundwater (Meinikmann et al., 2015)) and internal sources from the sediment compartment. In multiple cases, a reduction of external inputs did not efficiently reduce eutrophication because of internal sources associated with the massive amounts of nutrients accumulated in the sediments, as shown for phosphorus (P) by Søndergaard et al. (2003) or for nitrogen (N) by Jeppesen et al. (2005). For example, the modelling approach developed by Wu et al. (2017) on the eutrophic lake Dianchi (China) showed that internal loading contributed to $77 \%$ for total $\mathrm{P}$ and $72 \%$ for total $\mathrm{N}$ of the total inputs to the water column compared to external loading. Moreover, the contribution of internal sources of nutrients from sediments to water column eutrophication was the highest during the warm season of the year. Indeed, the release rate of $\mathrm{P}$ from lake sediments to the water column can be more than 12 -fold higher in late spring and summer than during other seasons (Penn et al., 2000; Qin et al., 2016).

For internal inputs, molecular diffusion is classically considered as the main mechanism influencing nutrient fluxes from the sediments to the water column (Berner, 1980 in Anschutz et al., 2012). Nevertheless, these fluxes are also known to be influenced by chemical (temperature, redox conditions, $\mathrm{pH}$ ), physical (hydrodynamics like water 
For instance, the solubility of phosphate $\left(\mathrm{PO}_{4}{ }^{3-}\right)$ ions is determined by oxygen availability due to their affinity with iron oxides. The $\mathrm{PO}_{4}{ }^{3-}$ ion can be adsorbed on the precipitated $\mathrm{Fe}(\mathrm{OH})_{3}-\mathrm{PO}_{4}$ complexes in presence of oxygen (Mortimer, 1941; Boström et al., 1988; Wetzel, 2001a). Phosphates can also precipitate with calcite $\left(\mathrm{CaCO}_{3}\right)$ in alkaline condition (as seen by House \& Denison, 2002). Bioturbation by benthic animals (i.e. sediment reworking and irrigation of biogenic structures such as tubes and burrows) also influences $\mathrm{N}$ and $\mathrm{P}$ dynamics at the water sediment interface. By modifying redox potentials and increasing water exchanges at the water-sediment interface, burrowing animals can stimulate the release of $\mathrm{N}$ (ammonium and/or nitrate) from interstitial water to the water column (e.g. Krantzberg, 1985). For example, Pelegri \& Blackburn, (1996) reported a 5.8-fold stimulation of ammonium $\left(\mathrm{NH}_{4}{ }^{+}\right)$release rates from lake sediments due to the bioturbation activities of Chironomus plumosus (2,000 larvae. $\left.\mathrm{m}^{-2}\right)$ in microcosms. Using a comparable experimental approach, Mermillod-Blondin et al. (2005) showed that tubificid worms $\left(20,000\right.$ individuals.m $\left.{ }^{-2}\right)$ increased the releases of $\mathrm{NH}_{4}{ }^{+}$, and $\mathrm{PO}_{4}{ }^{3-}$ from sediments by 2- and 4-fold, respectively. The influence of benthic fauna on nutrient fluxes at the water-sediment interface depends on their functional traits (building of biogenic structures, ventilation rate, depth of biogenic structures, sediment reworking rate) (Kristensen et al., 2012). For example, Nogaro et al. (2016) showed that chironomid larvae that build and ventilate U-shaped tubes stimulated P release from the sediment to the overlying water, whereas tubificids that produce gallery and egest fecal pellets at the water sediment interface increased P retention in sediment from eutrophic wetlands. Although the presence of Chironomus plumosus can contribute to release of nutrients into water column, they also bring oxygen into sediment and create oxic conditions nearby their burrow walls. These oxic conditions lead to trap phosphates in $\mathrm{Fe}(\mathrm{OH})_{3}-\mathrm{PO}_{4}$ complexes inside sediments (Hupfer et al., 2019).

Based on these findings, our study aimed to quantify the relative contribution of bioturbation and oxygen concentration conditions on nutrient fluxes at the water-sediment interface of a eutrophic reservoir during the warm season of the year when low oxygen conditions were expected to occur at the water-sediment interface. Laboratory experimentations in mesocosms mimicking the water-sediment interface of the studied reservoir were developed for evaluating the influences of bioturbating fauna (chironomid larvae, tubificid worms) and oxygen conditions in the water column (aerobic, anaerobic and fluctuating conditions) on nutrient $\left(\mathrm{N}^{-\mathrm{NH}_{4}}{ }^{+}, \mathrm{N}^{-\mathrm{NO}_{3}}{ }^{-}, \mathrm{P}^{-} \mathrm{PO}_{4}{ }^{3-}\right.$ and $\left.\mathrm{SiO}_{2}\right)$

101 released from sediments. For bioturbating fauna, oxygen uptake was also measured in the experiment as animals 102 can stimulate nutrient released from sediment by stimulating organic matter mineralization in sediments (Baranov 103 et al., 2016; Murniati et al., 2017; Saaltink et al., 2018). We expected that bioturbating fauna would significantly 104 increase the release of nutrients from sediments (Mermillod-Blondin et al., 2004). Moreover, due to higher 
ventilation of biogenic structures, the larvae of Chironomus plumosus would generate higher release rates of nutrients and oxygen uptake than tubificid worms (Nogaro et al., 2016). Concerning DO conditions, anaerobic conditions would enhance the release of nutrients, especially N-NH${ }_{4}^{+}$and $\mathrm{P}_{-} \mathrm{PO}_{4}{ }^{3-}$, compared with aerobic conditions. For the oxygen fluctuation treatment, we reproduced the daily variations of DO concentrations in the water column of eutrophic reservoirs (e.g. Balangoda, 2017; Wetzel, 2001b) by using the natural oxygen uptake of the sediment column without oxygen supply. Thus, oxygen fluctuations were expected to increase nutrient releases from sediments in comparison with aerobic conditions if oxygen uptake was high enough to produce aerobic-anaerobic fluctuations in the water column.

\section{Materials and methods}

\section{Study site presentation, sediment collection and preparation}

The study site is Puyvalador reservoir, which is regularly impacted by blooms of cyanobacteria (e.g., Synechococcus sp. and Anabaena spiroides) during the summer. This reservoir is located in the French Pyrenees Mountains $\left(42^{\circ} 38^{\prime} \mathrm{N}, 2^{\circ} 07^{\prime} \mathrm{E}\right)$ at altitude of $1421 \mathrm{~m}$. At its maximum storage level, its surface is 90 ha for a volume of $10.1 \mathrm{hm}^{3}$. The maximum depth is $21 \mathrm{~m}$ and the mean water residence time is 40 days. This reservoir is part of a hydroelectric complex operated by Electricité de France (EDF) and has two mains tributaries: Aude river and Galbe river. Puyvalador reservoir is eutrophic according to EU Water Framework Directive criteria (Agence de l'eau Rhône Méditerranée Corse, 2015). The central area of the reservoir of Puyvalador, where the depth is maximal, is the main sedimentation zone containing a high percentage $(80 \%)$ of fine particles $(<63 \mu \mathrm{m})$ compared to areas influenced by the tributaries (Gautreau et al. in prep). Sediments from the central area are characterized by concentrations of $45 \mathrm{~g}$. $\mathrm{kg}^{-1} \mathrm{DW}$ (dry weight) of total organic carbon, $6 \mathrm{~g} \mathrm{~kg}^{-1} \mathrm{DW}$ of total $\mathrm{N}$ and $0.5 \mathrm{~g} \mathrm{~kg}^{-1} \mathrm{DW}$ of total P, 33 g.kg ${ }^{-1} \mathrm{DW}$ of Fe, $342 \mathrm{mg} \cdot \mathrm{kg}^{-1} \mathrm{DW}$ of Mn, 4 g.kg-1 DW of Ca, and $34 \mathrm{~g}^{-\mathrm{kg}^{-1}} \mathrm{DW}$ of Al. Measurements of benthic fauna densities during summer period indicated that $4^{\text {th }}$ stage larvae of Chironomus plumosus and tubificid worms were the most abundant taxa with average densities of 2,095 individuals. $\mathrm{m}^{-2}$ and 18,190 individuals.m ${ }^{-2}$, respectively.

For the present experiment, sediments from the central area were collected with an Eckman grab in September 2017. After sampling, they were frozen at $-18^{\circ} \mathrm{C}$ for several weeks to kill the ambient fauna (Biles et al., 2002). In parallel, a subsample of unfrozen sediment was kept at $15^{\circ} \mathrm{C}$ (corresponding to the reservoir temperature at the water-sediment interface during sediment collection) to preserve the microbial activities of the collected sediments and to be used as an inoculum for the experiment. Fifteen days before mesocosm preparation, this subsample was 
134 sieved at $80 \mu \mathrm{m}$ to remove the ambient fauna and added to unfrozen sediments. This incubation time of 15 days

135 was long enough as Mermillod-Blondin et al. (2001) showed a bacterial recolonization of previously sterilized

136 sediments in less than 1 week.

138 Experiments were performed in 15 mesocosms made of Plexiglas cylinders with an internal diameter of $10 \mathrm{~cm}$ and

139 a height of $20 \mathrm{~cm}$ (Figure 1). Mesocosms were placed in a $15^{\circ} \mathrm{C}$ temperature-controlled room for mimicking

140 summer temperature at the water-sediment interface of the reservoir and filled with a layer of incubated sediments

$141(10 \mathrm{~cm})$ overlaid with synthetic water $(10 \mathrm{~cm})$ (composition of synthetic water: $96 \mathrm{mg} . \mathrm{L}^{-1} \mathrm{NaHCO}_{3} ; 39.4 \mathrm{mg} . \mathrm{L}^{-1}$

$142 \mathrm{CaSO}_{4} \cdot 2 \mathrm{H}_{2} \mathrm{O} ; 60 \mathrm{mg} \cdot \mathrm{L}^{-1} \mathrm{MgSO}_{4} \cdot 7 \mathrm{H}_{2} \mathrm{O} ; 4 \mathrm{mg} \cdot \mathrm{L}^{-1} \mathrm{KCl} ; \mathrm{pH}=7.5$; (US EPA, 1991)). Oxic conditions were

143 maintained in the mesocosms by bubbling water column with atmospheric air (Figure 1). Mesocosms were

144 equipped with peristaltic pumps for a continuous recirculation of the water column to avoid DO stratification but

145 water flow was adjusted to limit sediment resuspension $\left(6 \mathrm{~mL} \cdot \mathrm{min}^{-1}\right)$. Oxygen probes were placed on the

146 recirculation system of peristatic pumps to measure DO concentrations.

147 Mesocosms were run over a period of 14 days to homogenize the experimental conditions among systems. After

148 this period, we measured oxygen uptake in all mesocosms to make sure that similar aerobic microbial activities

149 were occurring in the sediment of all mesocosms. Afterwards, the water column of all mesocosms was renewed

150 with synthetic water to eliminate the initial flush of nutrients during the filling of mesocosms with sediments and

151 water.

152 Fig. 1 Schema of mesocosm installation with peristaltic pump, oxygen sensor and air source. Sediment and water 153 column compartments were $10 \mathrm{~cm}$ in height, corresponding to a volume of $0.785 \mathrm{~L}$ for each compartment.

155 A total of 15 mesocosms was set up to quantify the influence of fauna and DO on nutrient fluxes. For testing the 156 influence of fauna, the water column of the mesocosms was saturated in DO. Three conditions were tested with 157 three mesocosms per condition: 1) control mesocosms without fauna, 2) mesocosms with addition of 150 tubificid 158 worms (more than $90 \%$ belonging to the species Tubifex tubifex, Michel Lafond, pers. com) and 3) mesocosms 159 with addition of $154^{\text {th }}$ stage larvae of Chironomus plumosus. Tested animals were from professional breeders.

160 Densities (19,230 individuals per $\mathrm{m}^{2}$ for tubificid worms and 1,923 individuals per $\mathrm{m}^{2}$ for Chironomus plumosus)

161 fitted with natural densities measured in the field in summer (see Study site presentation). Three conditions with 
three replicated mesocosms per condition were used to test the influence of DO concentrations on nutrient fluxes:

163 1) mesocosms with a water column saturated in DO (same systems than those used as control mesocosms without

164 fauna), 2) mesocosms without fauna and experiencing DO decrease every 12 hours (aeration turn on and off every

16512 hours), 3) mesocosms without fauna experiencing anaerobic conditions in the water column.

Nutrient dynamics and aerobic microbial respiration were measured during the 15 days of experiment to study the effects of oxygen conditions and bioturbation on biogeochemical processes. Nutrient dynamics were measured by collecting water samples from the water column at 7 times: on Day 0 just before the treatment application and on days 3, 6, 8, 10, 13 and 15 after the treatment application. At each sampling date, a volume of $30 \mathrm{~mL}$ of overlying water was sampled from the top of the water column and filtered through a GF/F filters ( $0.7 \mu \mathrm{m}$, Whatman) and conserved at $4{ }^{\circ} \mathrm{C}$ before chemical analyses. $\mathrm{N}-\mathrm{NH}_{4}{ }^{+}, \mathrm{N}-\mathrm{NO}_{3}{ }^{-}, \mathrm{P}_{-} \mathrm{PO}_{4}{ }^{3-}$ and $\mathrm{SiO}_{2}$ concentrations of all samples were determined by colorimetric methods with a sequential analyzer (SmartChem200, AMS Alliance). During the experiment, the sampled volume of water for analyses $(30 \mathrm{~mL})$ was replaced with $30 \mathrm{~mL}$ of artificial water for keeping a constant volume of overlying water. Moreover, to prevent oxygenation of anoxic mesocosms during sampling, collected water was replaced by synthetic water at the top of the mesocosms without air entrance.

DO fluxes were measured to evaluate the influence of bioturbating fauna on aerobic microbial respiration. These measurements were performed a day before fauna introduction (day -1) and on days 2, 7 and 14 after the addition of fauna. At each sampling date, mesocosms were sealed for avoiding contact with the atmosphere and the incubation time was limited to 4 hours to avoid the decrease of DO concentrations below $5 \mathrm{mg} . \mathrm{L}^{-1}$. DO was

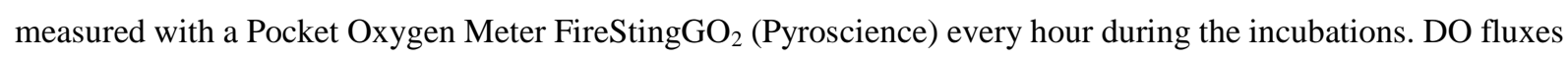
in the mesocosms were calculated from the linear decrease of DO over time and expressed as $\mu$ mol of $\mathrm{O}_{2}$ consumed per hour and $\mathrm{m}^{2}$ of sediment surface.

185 For chemical variables and DO fluxes measured at different times (after the treatment application), the effect of 186 fauna was tested using one-way repeated measures analyses of variance (RM-ANOVAs) on days 3, 6, 8, 10, 13 187 and 15 for nutrients concentrations and 2, 7 and 14 for DO fluxes with fauna treatment (i.e. control without fauna, 188 chironomids, and tubificids treatments) as the main effect. The effect of DO was also tested by one-way RM- 
fluctuation, and anoxia treatments) as the main effect. When one-way RM-ANOVAs were significant (i.e.,

$191 \mathrm{p}<0.05$ ), Tukey's post hoc tests were performed for the last day of the experiment to evaluate which treatments

192 differed after 15 days of mesocosm stabilization. For all variables and before statistical analyses, the normality

193 and the homoscedasticity of the residues were verified using the Shapiro-Wilk's test and the Bartlett's test,

194 respectively. All statistical analyses were done with the R v.3.3.2 software.

195 Results

Influence of bioturbation on nutrient dynamics, nutrient release rates and DO fluxes

During the experiment, sediments of control mesocoms presented a dark color characteristics of anoxic conditions

(Fig. 2A). Chironomid larvae produced U-shaped tubes in the top $5 \mathrm{~cm}$ of the sediment (Fig. 2B). The ventilation of these structures by the chironomids produced a brown colored oxic zone on the tube walls surrounded by dark colored anoxic sediments in the non-bioturbated zones (Fig 2B). Tubificid worms dug galleries in the whole sediment column (10 cm deep, Fig 2C) and deposited fecal pellets at the sediment surface. Nevertheless, we did not observe any brown oxidized zone on the gallery walls produced by the tubificid worms.

Fig. 2 Pictures from the mesocosms: (A) control treatment without fauna, (B) U-shaped tubes produced by chironomid larvae on the inner wall of a mesocosm and (C) galleries produced by tubificid worms on the inner wall of a mesocosm.

$\mathrm{N}-\mathrm{NH}_{4}{ }^{+}$concentrations measured in the water column of all treatments significantly increased during the first 6 to 8 days of the experiment and decreased thereafter (Figure 3A, one-way RM-ANOVA, time effect, $* * * \mathrm{p}<0.0001$ ).

210 This initial $\mathrm{N}-\mathrm{NH}_{4}{ }^{+}$increase was significantly higher in the chironomid treatment compared to the control and 211 tubificid treatments (one-way RM-ANOVA, fauna treatment, *p < 0.01). Nevertheless, after 15 days of mesocosm 212 stabilization with fauna, $\mathrm{N}-\mathrm{NH}_{4}{ }^{+}$concentrations were comparable in control, tubificid worm and chironomid treatments (Tukey's test, p-value $>0.05$ ).

$214 \mathrm{~N}-\mathrm{NO}_{3}{ }^{-}$concentrations measured in the water column significantly increased during the course of the experiment 215 from $0.1 \mathrm{mg} . \mathrm{L}^{-1}$ at day 0 to $1.1,2.2$ and $3.4 \mathrm{mg} \cdot \mathrm{L}^{-1}$ at the end of the experiment for the control, the tubificid and the chironomid treatments, respectively (Figure 3B, one-way RM-ANOVA, time effect, ***p <0.0001). These N- 
$217 \mathrm{NO}_{3}{ }^{-}$increases differed over time depending on the treatment (one-way RM-ANOVA, "fauna treatment * time" 218 effect, $* * * p<0.0001)$. Significant $\mathrm{N}^{-\mathrm{NO}_{3}}{ }^{-}$increases occurred on the first days for the controls and in presence of 219 tubificids whereas $\mathrm{N}-\mathrm{NO}_{3}{ }^{-}$concentrations increased between day 6 and day 13 in presence of chironomids (Figure 220 3B). Such $\mathrm{N}_{-} \mathrm{NO}_{3}{ }^{-}$increase in the chironomid treatment was concomitant with the $\mathrm{N}-\mathrm{NH}_{4}{ }^{+}$decrease of 221 concentration in the water column (Figure 3A). At the end of the experiment, $\mathrm{N}_{-} \mathrm{NO}_{3}{ }^{-}$concentrations were significantly higher in the chironomid treatment compared to the control and tubificid treatments (Tukey's tests, p-value $<0.05)$. Considering both inorganic $\mathrm{N}_{-} \mathrm{NH}_{4}{ }^{+}$and $\mathrm{N}-\mathrm{NO}_{3}{ }^{-}$, concentrations, inorganic $\mathrm{N}$ concentrations measured on day 15 in chironomid and tubificid treatments were 3.7-fold and 2-fold higher than in control treatment, respectively (Tukey's tests, p-value $<0.05$ ).

$\mathrm{P}-\mathrm{PO}_{4}{ }^{3-}$ concentrations measured in the water column in presence of chironomids significantly increased from 1 $\mu \mathrm{g} . \mathrm{L}^{-1}$ at day 0 to $60 \mu \mathrm{g} . \mathrm{L}^{-1}$ at day 6 and then decreased to reach $21 \mu \mathrm{g} . \mathrm{L}^{-1}$ at day 15 (Figure 3C). In comparison, $\mathrm{P}-\mathrm{PO}_{4}{ }^{3-}$ concentration in the water column of control and tubificid treatments remained below $10 \mu \mathrm{g} . \mathrm{L}^{-1}$ during the whole course of the experiment. Then, after 15 days of experiment, $\mathrm{P}-\mathrm{PO}_{4}{ }^{3-}$ concentrations in chironomid treatment was 17-fold higher than those measured in control treatment. Despite low $\mathrm{P}_{-} \mathrm{PO}_{4}{ }^{3-}$ concentrations, the occurrence of tubificid worms also increased by 3 -fold $\mathrm{P}-\mathrm{PO}_{4}{ }^{3-}$ concentrations in water column in comparison with control treatment (Tukey test, p-value $<0.05$ ).

$233 \mathrm{SiO}_{2}$ concentrations measured in the water column significantly increased in all treatments during the course of 234 the experiment (Figure 3D, one-way RM-ANOVA, time effect, ***p $<0.0001$ ) and reached 20 mg.L ${ }^{-1}$ for the 235 chironomid treatment and $13 \mathrm{mg} . \mathrm{L}^{-1}$ for the control and tubificid treatments at day 15 (one-way RM-ANOVA, 236 treatment effect, $\left.{ }^{*} \mathrm{p}<0.01\right)$. Such $\mathrm{SiO}_{2}$ increase was significantly higher in the chironomid treatment than in other 237 treatments (Tukey's tests, $* \mathrm{p}<0.01$ ). At day 15 , concentration of $\mathrm{SiO} 2$ was 1.4 -fold higher in chironomid 238 treatment than in control treatment.

240 DO uptake rates were comparable in all mesocosms before the fauna addition (around $1500 \mu \mathrm{mol} \cdot \mathrm{h}^{-1} \cdot \mathrm{m}^{-2}$ ) and 241 significantly varied during the course of the experiment with the highest rates measured on day 7 (Figure 4, one242 way RM-ANOVA, time effect, $* * * p<0.0001)$. After the fauna addition, the presence of chironomid larvae 243 significantly increased oxygen uptake rates in comparison with the other treatments (one-way RM-ANOVA, 244 treatment effect, $* * * p<0.0001$; Tukey’s tests, $\mathrm{p} *<0.01)$. For example, mean DO uptake rate measured on day 24514 was 2 -fold higher in the chironomid treatment (i.e. $2665 \mu$ mol.hour ${ }^{-1} \cdot \mathrm{m}^{-2}$ ) than in the control treatment (i.e. 
$2461196 \mu$ mol.hour ${ }^{-1} \cdot \mathrm{m}^{-2}$ ). Mean DO uptake rates measured in tubificid treatment were slightly higher than in control treatment but this effect was not statistically significant at all dates (see post-hoc Tukey's tests in Figure 248 4).

249 Fig. 3 Concentrations of $\mathrm{N}_{-} \mathrm{NH}_{4}{ }^{+}(\mathrm{A}), \mathrm{N}_{-} \mathrm{NO}_{3}{ }^{-}(\mathrm{B}), \mathrm{P}_{-} \mathrm{PO}_{4}{ }^{3-}$ (C), and $\mathrm{SiO}_{2}$ (D) measured in the water column of mesocosms during the course of the experiment for the three fauna treatments (mean \pm standard error, $n=3$ ).

251 Fig. 4 Oxygen uptake rates (fluxes from water column to sediment) measured for the three fauna treatments (mean $252 \pm$ standard error, $\mathrm{n}=3$ mesocosms). For each panel, different letters (A, B and C) show significant differences 253 among treatments (see axis label, Tukey post hoc test, $\mathrm{p}<0.05$ ).

Influence of oxygen conditions in the water column on nutrient dynamics and release rates

255 Our experimental approach allowed generating contrasted oxic/anoxic conditions in the water column for the three 256 treatments. DO concentrations were maintained above $9 \mathrm{mg} / \mathrm{L}$ in the water column for the DO-saturated control treatment whereas they were below $0.05 \mathrm{mg} / \mathrm{L}$ in the anoxic treatment during the whole experiment. In the DO 258 fluctuation treatment, DO concentrations varied daily from $9 \mathrm{mg} / \mathrm{L}$ during the water column aeration to $5 \mathrm{mg} / \mathrm{L}$ about $12 \mathrm{~h}$ after the shutdown of the water column aeration (Supplementary Material 1).

$260 \mathrm{~N}^{-\mathrm{NH}_{4}}{ }^{+}$concentration measured in the water column significantly increased from $0.5 \mathrm{mg} . \mathrm{L}^{-1}$ to $6.4 \mathrm{mg} . \mathrm{L}^{-1}$ 261 during the course of the experiment in the anoxia treatment whereas only small variations in $\mathrm{N}^{-\mathrm{NH}_{4}}{ }^{+}$ 262 concentrations were measured in the DO-saturated control and the DO fluctuation treatments (Figure 5A, one-way 263 RM-ANOVA, "treatment * time" effect, $* * * p<0.0001)$. Indeed, at the end of the experiment, concentration of $\mathrm{N}-$ $264 \mathrm{NH}_{4}{ }^{+}$was 102-fold time higher in anoxia treatment than in DO-saturated control treatment (Tukey's tests, ${ }^{*} \mathrm{p}<$ $2650.01)$.

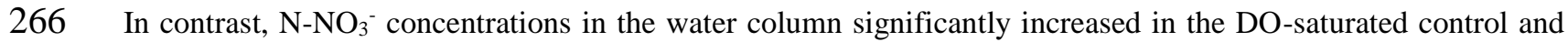
267 DO-fluctuation treatments from $0 \mathrm{mg} \cdot \mathrm{L}^{-1}$ on day 0 to about $1 \mathrm{mg} \cdot \mathrm{L}^{-1}$ from day 3 to day 15 whereas $\mathrm{N}^{-\mathrm{NO}_{3}}$ 268 concentrations in the anoxia treatment remained low (around $0.04 \mathrm{mg} . \mathrm{L}^{-1}$ ) throughout the experiment (Figure 5B,

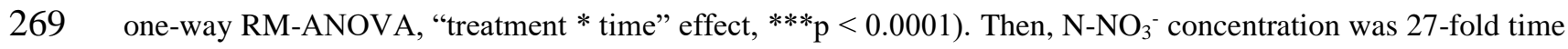
270 higher in control treatment than in anoxia treatment at the end of the experiment (Tukey’s tests, *p $<0.01$ ).

271 Similarly to $\mathrm{N}-\mathrm{NH}_{4}{ }^{+}$dynamics, $\mathrm{P}_{-} \mathrm{PO}_{4}{ }^{3-}$ concentrations in the water column significantly increased from 0 to 1034 $272 \mu \mathrm{g} . \mathrm{L}^{-1}$ during the course of the experiment in the anoxia treatment whereas $\mathrm{P}-\mathrm{PO}_{4}{ }^{3-}$ concentrations remained low 273 (around $3 \mu \mathrm{g} . \mathrm{L}^{-1}$ ) in the two other treatments (Figure 5C, one-way RM-ANOVA, "treatment * time" effect, ***p 
$274<0.0001)$. At the end of the experiment, concentration of $\mathrm{P}_{-} \mathrm{PO}_{4}{ }^{3-}$ in the water column was 56-fold time higher in 275 anoxia treatment than in control treatment (Tukey’s tests, $* \mathrm{p}<0.01$ ).

$276 \mathrm{SiO}_{2}$ concentration measured in the water column significantly increased in all treatments during the course of the 277 experiment (Figure 5D, one-way RM-ANOVA, time effect, ***p < 0.0001) with higher increases detected in the 278 anoxia treatment (e.g., $19.2 \mathrm{mg} . \mathrm{L}^{-1}$ at day 15 ) compared to the other treatments (e.g., about 13-14 mg. $\mathrm{L}^{-1}$ at day15) 279 (one-way RM-ANOVA, treatment effect, *p $<0.01$ ).

280 Fig. 5 Dynamics of $\mathrm{N}-\mathrm{NH}_{4}{ }^{+}(\mathrm{A}), \mathrm{N}-\mathrm{NO}_{3}{ }^{-}(\mathrm{B}), \mathrm{P}_{-} \mathrm{PO}_{4}{ }^{3-}(\mathrm{C})$, and $\mathrm{SiO}_{2}$ (D) measured in the water column during the 281 course of the experiment for the three DO treatments (mean \pm standard error, $n=3$ ).

$282 *$ Concentrations of $\mathrm{P}-\mathrm{PO}_{4}{ }^{3-}$ in the anoxia treatment at day 15 are lacking due to an analytical problem.

\section{Discussion}

\section{Influence of fauna on the dynamics of nutrients in water column}

285 Nutrient concentrations in water column were highly variable during the course of the experiment in fauna 286 treatments. More precisely, the occurrence of chironomids in mesocosms produced peaks of $\mathrm{N}-\mathrm{NH}_{4}{ }^{+}$and $\mathrm{P}-\mathrm{PO}_{4}{ }^{3-}$ 287 in the water column during the first 8 days of experiment. These releases of reduced compounds $\left(\mathrm{N}-\mathrm{NH}_{4}{ }^{+}\right.$and $\mathrm{P}-$ $288 \mathrm{PO}_{4}^{3-}$ ) from the pore water of sediments were more probably due to the initial installation (building and 289 ventilation of U-shaped tubes) of chironomids in poorly-oxygenated sediments (as illustrated in Figure 6). This 290 effect of chironomid larvae on the flush of reduced compounds from sediments to the water column has been 291 commonly observed in experimental studies with organic-rich lake sediments (Pelegri \& Blackburn, 1996; 292 Hansen et al., 1998; Stief \& De Beer, 2006). Nevertheless, this effect was temporary in the present experiment 293 and, after an initial flush, $\mathrm{N}_{-} \mathrm{NH}_{4}{ }^{+}$concentrations decreased concomitantly with an increase of $\mathrm{N}^{-\mathrm{NO}_{3}}{ }^{-}$ 294 concentrations in the water column. This evolution of inorganic $\mathrm{N}$ compounds in the water column corresponds to 295 a classic sequence of nitrification (Bowen et al., 2014; Pigneret et al., 2016), which was more likely performed by 296 aerobic microorganisms present in the oxygen-saturated water column and the top oxidized sediment layer. 297 Since this process was mainly detected in presence of chironomids, we also expect that the burrow walls acted as 298 a very active zone for nitrification. Several authors demonstrated that burrow construction and ventilation by 299 Chironomus plumosus could increase the aerobic surface of the water-sediment interface, and then the favorable 300 zones for nitrification and coupled nitrification-denitrification (Pelegri \& Blackburn, 1996; Svensson \& 301 Leonardson, 1996; Lewandowski \& Hupfer, 2005; Lewandowski et al., 2007; Moraes et al., 2018). This effect 
was illustrated on Figure 2B with oxidized sediment nearby U-shaped tubes. Therefore, after 15 days of 303 stabilization, the influence of chironomid larvae bioturbation on $\mathrm{N}$ fluxes was predominantly associated with a 304 release of ${\mathrm{N}-\mathrm{NO}_{3}}^{-}$from oxidized sediments (Figure 6B) than a release of $\mathrm{N}^{-} \mathrm{NH}_{4}{ }^{+}$from poorly-oxygenized sediments (as observed during chironomid installation, Figure 6A). Concerning P dynamics, the presence of

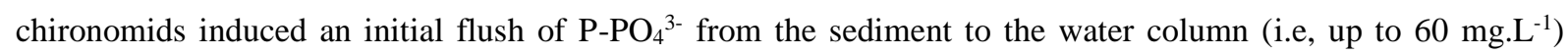

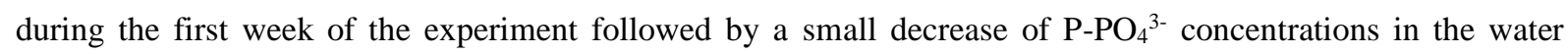
column the second week of the experimentation, which remained around 30-40 $\mu \mathrm{g} \cdot \mathrm{L}^{-1}$ until the end of the experiment. Then, the stimulating effect of chironomid ventilation on $\mathrm{P}_{-} \mathrm{PO}_{4}{ }^{3-}$ concentrations compared to the control treatment without fauna was detected until the end of the experiment. According to Lewandowski and Hupfer (2005) and Hupfer et al. (2019), the supply of DO in chironomid burrows could have produced an adsorption of the $\mathrm{P}_{-} \mathrm{PO}_{4}{ }^{3-}$ initially flushed in the water column into $\mathrm{Fe}(\mathrm{OH})_{3}-\mathrm{PO}_{4}$ complexes in Fe-rich sediments (ie. 33 g. $\mathrm{kg}^{-1} \mathrm{DW}$ of total Fe, see materials and methods). Such mechanism probably occurred during our

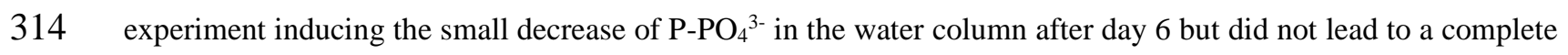

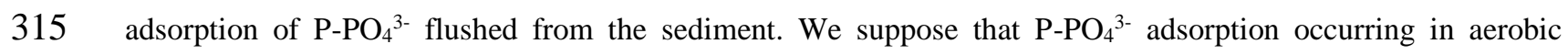

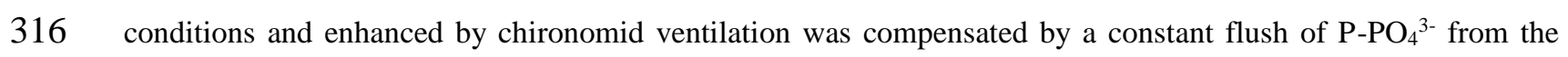
anoxic sediments due to chironomid bioturbation (Figure 6). As the dynamics of nutrients during the course of

318 the experiment in chironomid treatment were largely associated with the installation of benthic chironomid 319 larvae in sediments, we compared the effects of three fauna treatments on nutrients in water column by considering the last day of the experiment after 15 days of stabilization of biogeochemical processes in the mesocosms.

\section{Influence of bioturbation on nutrient concentrations and oxygen uptake}

323 According to our prediction, the ventilation of U-shaped burrows by Chironomus plumosus highly increased 324 inorganic $\mathrm{N}$ (x 3.7) and $\mathrm{P}_{-} \mathrm{PO}_{4}{ }^{3-}$ (x 17) concentration in water column after 15 days of experiment by creating water 325 exchanges at the water sediment interface. Indeed, the presence of oxic brown sediments observed on the burrow 326 walls of chironomids demonstrated a transport of oxygen-saturated water from the water column in the biogenic 327 structures built by animals in anoxic sediments. This ventilation of U-shaped burrows produced a significant 328 stimulation of oxygen uptake (2-fold increase on day 7 compared to control treatment without fauna) by increasing 329 the supply of DO in sediments. This stimulation of oxygen uptake by chironomids probably contributed to nutrient 330 dynamics by stimulating microbial activities and organic matter mineralization in sediments (Aller, 2001). 331 Nevertheless, the major mechanism explaining the influence of chironomid larvae on nutrient fluxes at the water- 
sediment interface was burrow ventilation which increased the release rates of nutrients (inorganic nitrogen $\mathrm{N}$ -

$333 \mathrm{NH}_{4}{ }^{+}+\mathrm{N}-\mathrm{NO}_{3}{ }^{-}-$and $\mathrm{P}_{-} \mathrm{PO}_{4}{ }^{3-}$ ) accumulated in pore water (Lewandowski \& Hupfer, 2005; Lewandowski et al.,

334 2007). The increase (+50\%) of $\mathrm{SiO}_{2}$ concentration in water column with Chironomus plumosus was in accordance

335 with this mechanism of burrow ventilation as silicate fluxes were found to depend on irrigation of biogenic

336 structures by benthic fauna (e.g., Mermillod-Blondin et al., 2004).

337 In contrast with chironomid larvae, tubificid worms had lower influences on $\mathrm{N}$ ( $\mathrm{x} 2$ in comparison with the control

338 treatment) and $\mathrm{P}$ ( $\mathrm{x} 3$ in comparison with the control treatment) concentrations in the water column in our

339 experimental conditions. Such contrasted effects of Chironomus plumosus and tubificid worms on nutrient

340 concentrations were related to their different bioturbation activities in the sediment. Tubificid worms produce deep

341 biogenic structures in the sediment column but they do not ventilate their galleries to the same extent as

342 chironomids (Leuchs, 1986; Wood, 1975 in Svensson et al., 2001). In presence of tubificid worms, $\mathrm{SiO}_{2}$

343 concentrations were not significantly different compared to the controls without fauna, indicating that tubificids

344 did not strongly enhance water exchanges, oxygen uptake and release of reduced compounds $\left(\mathrm{N}-\mathrm{NH}_{4}{ }^{+}\right.$and $\mathrm{P}_{-} \mathrm{PO}_{4}{ }^{3-}$

345 ) at the water-sediment interface (Figure 7). Our results contrasted with several studies showing a significant

346 stimulating effect of tubificid worms on oxygen uptake at the water sediment interface (Fukuhara \& Sakamoto,

347 1987; Mermillod-Blondin \& Rosenberg, 2006; Saaltink et al., 2018). For example, Mermillod-Blondin et al. (2008)

348 showed that tubificid worms at a density $\left(21,000\right.$ individuals. $\left.\mathrm{m}^{-2}\right)$ close to those used in our experiment $(19,230$

349 individuals. $\mathrm{m}^{-2}$ ) stimulated by around 2-fold oxygen uptake from sediments rich in organic matter. Such

350 contrasting results were more likely due to differences in sediment characteristics, which could largely modulate

351 the functional significance of bioturbation at the water-sediment interface (e.g. Nogaro et al., 2016). In the present

352 study, total organic carbon concentrations in sediments were indeed 4-fold lower than concentrations in sediments

353 tested by Mermillod-Blondin et al. (2008) (i.e. about 4.5\% vs. 20\% DW, respectively). Sediment organic content

354 could have a significant influence on nutrient dynamics because the microbial mineralization of organic matter in

355 the sediment determines (1) the production of inorganic nutrients $\left(\mathrm{N}^{-} \mathrm{NH}_{4}{ }^{+}\right.$and $\left.\mathrm{P}^{-} \mathrm{PO}_{4}{ }^{3-}\right)$ and (2) the redox

356 conditions in the sediment column (Forsberg, 1989; Kristensen, 2000). Lower sediment organic content in our

357 study might have induced lower microbial activity and associated redox conditions (eg, more oxygen, less

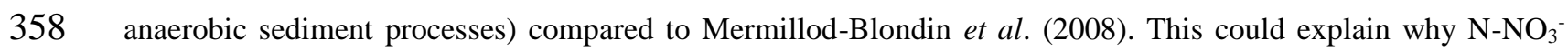

359 released from sediments was higher in the present study than $\mathrm{N}^{-\mathrm{NH}_{4}}{ }^{+}$released in presence of tubificids compared

360 to control treatment (Figure 3) whereas $\mathrm{N}^{-\mathrm{NH}_{4}}{ }^{+}$concentrations dominated inorganic $\mathrm{N}$ fluxes in Mermillod-

361 Blondin et al. (2008). Therefore, we hypothesize that the role of bioturbation in nutrient dynamics is tightly linked 
to the sediment organic content (and associated redox conditions) but further experiments using a wide variety of sediments are needed to clarify this link.

364 Fig. 6 Summary of the main influence of fauna bioturbation processes on water fluxes and associated nutrient 365 fluxes: (A) burrow construction and ventilation by Chironomus plumosus during the first week and (B) during the 366 second week. The arrows from the water to the sediment compartment represent the fluxes of water and DO (larger 367 arrow means larger fluxes). Arrows from the sediment to the water compartment show the release of nutrients. Influence of the oxygenation treatment on nutrient fluxes According to our prediction, the anoxia treatment increased by 102 -fold $\mathrm{N}_{-} \mathrm{NH}_{4}{ }^{+}$concentrations and by 56 -fold $\mathrm{P}$ $\mathrm{PO}_{4}{ }^{3-}$ concentrations in comparison with the well-oxygenated control treatment. In contrast, the treatment with DO-fluctuations did not affect nutrient fluxes in comparison with the control treatment because sediment DO uptake was not high enough to produce anoxic conditions in the water column (DO concentrations never dropped below $5 \mathrm{mg} . \mathrm{L}^{-1}$ during the experiment). In consequence, DO fluctuations had no significant effect on $\mathrm{P}$ released from sediment as desorption of $\mathrm{P}$ from $\mathrm{Fe}, \mathrm{Mn}, \mathrm{Al}$ or $\mathrm{Ca}$ only occurs under anoxic conditions (Dahm et al., 1987 in Boulton et al., 1998). Moreover, the Fe:P ratio (by weight) in Puyvalador sediments is around 66 (so above 15) and can control internal P loading in presence of oxygen (Jensen et al., 1992). Moreover, DO fluctuations did not stimulate organic matter mineralization in sediments, a mechanism reported by Aller (2001) in marine sediments.

Several studies highlighted that anaerobic condition in the water column was a major factor for the release rates

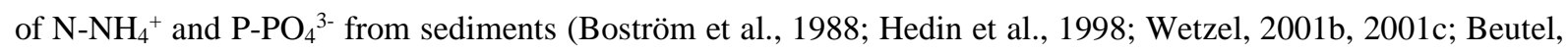
381 2006; Ekeroth et al., 2016; Rapin et al., 2019). Indeed, ${\mathrm{N}-\mathrm{NH}_{4}+}^{+}$produced by organic matter mineralization was

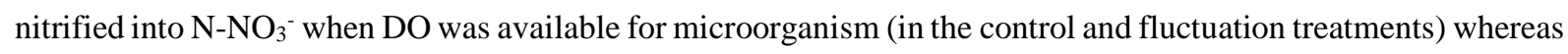

$383 \mathrm{~N}-\mathrm{NH}_{4}{ }^{+}$accumulated in anoxic conditions (in the anoxic treatment). Therefore, fluxes of inorganic $\mathrm{N}$ 384 from the sediment to the water column were dominated by $\mathrm{N}^{-\mathrm{NO}_{3}}{ }^{-}$fluxes in the control and fluctuation treatments 385 and by $\mathrm{N}-\mathrm{NH}_{4}{ }^{+}$in the anoxic treatment (Figure 7). P fluxes were linked with adsorption mechanisms modulated

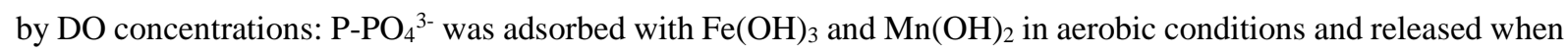
oxygen was limited (Figure 7). Surprisingly, $\mathrm{SiO}_{2}$ fluxes from sediment to water column were also stimulated by anoxic conditions whereas the $\mathrm{SiO}_{2}$ dynamics was not dependent on redox conditions like $\mathrm{P}$ or $\mathrm{Fe}$ which precipitated in oxic conditions (Tessenow, 1972 in Granéli, 1979). We can suppose that this increase of $\mathrm{SiO}_{2}$ fluxes under anoxic conditions was associated with the production and ebullition of $\mathrm{CH}_{4}$ bubbles produced in sediments 
391 during the experiment. Indeed, production of gas has been observed in the anoxic treatment during the course of 392 the experiment and it has been shown that the ebullition of $\mathrm{CH}_{4}$ could be as a significant driver of water fluxes and 393 associated dissolved solutes from pore water to water column (Klein, 2006; Cheng et al., 2014). Consequently, 394 such process might have contributed to the releases of $\mathrm{SiO}_{2}$ but also reduced nutrients $\left(\mathrm{N}-\mathrm{NH}_{4}{ }^{+}\right.$and $\left.\mathrm{P}-\mathrm{PO}_{4}{ }^{3-}\right)$ from 395 pore water to water column.

396 Fig. 7 Summary of the main influence of DO conditions in the water column on nutrient fluxes (A) oxic conditions 397 and (B) anoxic conditions.

\section{Conclusions}

The present study showed that natural densities of Chironomus plumosus larvae could increase N $\left(\mathrm{N}-\mathrm{NH}_{4}{ }^{+}+\mathrm{N}_{-}\right.$

$400 \mathrm{NO}_{3}{ }^{-}$) and $\mathrm{P}_{-} \mathrm{PO}_{4}{ }^{3-}$ release rates by 3.7- and 17-fold, respectively. Anoxic conditions in the water column had 401 higher influences on $\mathrm{N}$ (x102 in comparison with the control) and $\mathrm{P}$ (x56 in comparison with the control) 402 concentrations in the water column than the most efficient bioturbator - chironomid larvae - (x3.7 for $\mathrm{N}$ and $\mathrm{x} 17$ for P). These results confirmed the main conclusion of Ekeroth et al. (2016) in marine sediments which stated that 404 oxygen condition was a stronger regulator of $\mathrm{P}$ fluxes than benthic fauna. The higher influence of anoxia on $\mathrm{N}$ release from sediments in comparison with bioturbation was more surprising and can be due to a lack of 406 denitrification in anoxic conditions. Indeed, the stimulating influence of ventilated U-shaped tubes on nitrificationdenitrification coupling reported in several studies (Svensson \& Leonardson, 1996; Moraes et al., 2018) might 408 have led to $\mathrm{N}$ loss from chironomid mesocosms (NH4 $\rightarrow$ NO3 $\rightarrow$ N2) and then a limitation of inorganic dissolved $409 \mathrm{~N}$ accumulated in the water column during the course of the experiment. In contrast, the lack of nitrification in 410 anoxic conditions might have suppressed $\mathrm{N}-\mathrm{NO}_{3}{ }^{-}$denitrification and produced a high accumulation of $\mathrm{N}-\mathrm{NH}{ }^{+}{ }^{+}$in 411 the water column during the course of the experiment. Nevertheless, this explanation needs to be verified by 412 measuring the denitrification potential in each experimental treatment.

413 Overall, we can conclude that the presence of efficient bioturbating fauna and anoxia at the sediment-water 414 interface should not be neglected in the evaluation of nutrient dynamics in lake sediments during the warmer 415 season of the year. This demonstrates the need to integrate environmental biogeochemistry with the dynamics of 416 benthic invertebrates to provide reliable and ecologically relevant assessments of nutrient cycling in reservoirs. 417 Nevertheless, nutrient dynamics in sediments can be largely dependent on several factors linked to sediment 418 characteristics such as organic matter concentration and Fe content (e.g., Forsberg, 1989; Jensen et al., 1992). 419 Extending our experimental approach to several reservoir sediments is greatly needed to evaluate how the role of 
420 bioturbation and anoxia on nutrient dynamics depends on sedimentary characteristics. This is a necessary step to

421 develop a more generalized framework on the contribution of environmental factors on nutrient dynamics in

422 reservoirs during the warm season that may be subject to algal blooms.

423

424

425

426

427

428

429

430

431

432

433

434

435

436

437

438

439

440

441

442

443

444

445

446

447

448

\section{Supplementary material}

Online Resource 1 (A) Concentration of dissolved oxygen $\left(\mathrm{mg} . \mathrm{L}^{-1}\right)$ in control treatment from day 2 to day 14, (B) concentration of dissolved oxygen $\left(\mathrm{mg} . \mathrm{L}^{-1}\right)$ in anoxia treatment from day 2 to day 14 and (C) concentration of dissolved oxygen (mg.L $\left.\mathrm{L}^{-1}\right)$ monitored in fluctuation treatment from day 12 to day 15 .

\section{Author's contributions}

All authors contributed to the study conception and design. Material preparation, data collection and analysis were performed by Edwige Gautreau, Florian Mermillod-Blondin and Laurence Volatier. The first draft of the manuscript was written by Edwige Gautreau, Florian Mermillod-Blondin and Laurence Volatier. All authors contributed critically to the drafts and gave final approval for publication.

\section{Ethical approval}

All applicable international, national, and/or institutional guidelines for the care and use of animals were followed.

\section{Funding}

This study was funded by the partnership EDF-CNRS (CNRS n ${ }^{\circ 49389)}$ and Lyon Metropole within the framework of Sedaqua Platform (Contrat Plan Etat Région).

\section{Conflict of Interest}

The authors declare that they have no conflict of interest.

\section{Bibliography}

Agence de l'eau Rhône Méditerranée Corse, 2015. Suivi des plans d'eau des bassins Rhône-Méditerranée et Corse en application de la Directive Cadre sur l'Eau (Sites de Référence, Réseau de Contrôle de Surveillance et Contrôle Opérationnel) Note synthétique d'interprétation des résultats Puyvalador (66: Pyrénées-Orientales) Campagnes 2013. 
Aller, R. C., 2001. Transport and reaction in the bioirrigated zone. The benthic boundary layer: transport processes and biogeochemistry. Oxford University Press: 269.

Anschutz, P., A. Ciutat, P. Lecroart, M. Gérino, \& A. Boudou, 2012. Effects of tubificid worm bioturbation on freshwater sediment biogeochemistry. Aquatic Geochemistry 18: 475-497. Journal of Environmental Sciences 13: 30-46.

Baranov, V., J. Lewandowski, P. Romeijn, G. Singer, \& S. Krause, 2016. Effects of bioirrigation of non-biting midges (Diptera: Chironomidae) on lake sediment respiration. Scientific Reports 6:, http://www.nature.com/articles/srep27329.

Berner, R. A., 1980. Early diagenesis: a theoretical approach. Princeton University Press, Princeton, N.J.

Beutel, M. W., 2006. Inhibition of ammonia release from anoxic profundal sediments in lakes using hypolimnetic oxygenation. Ecological Engineering 28: 271-279.

Biles, C., D. Paterson, R. Ford, M. Solan, \& D. Raffaelli, 2002. Bioturbation, ecosystem functioning and community structure. Hydrology and Earth System Sciences Discussions 6: 999-1005.

Boström, B., J. M. Andersen, S. Fleischer, \& M. Jansson, 1988. Exchange of phosphorus across the sedimentwater interface In Persson, G., \& M. Jansson (eds), Phosphorus in freshwater ecosystems. Springer Netherlands, Dordrecht: 229-244, http://www.springerlink.com/index/10.1007/978-94-009-3109-1_14.

Boulton, A. J., S. Findlay, P. Marmonier, E. H. Stanley, \& H. M. Valett, 1998. The functional significance of the hyporheic zone in streams and rivers. Annual Review of Ecology and Systematics 29: 59-81.

Bowen, J. L., A. R. Babbin, P. J. Kearns, \& B. B. Ward, 2014. Connecting the dots: linking nitrogen cycle gene expression to nitrogen fluxes in marine sediment mesocosms. Frontiers in Microbiology 5:, 470 http://journal.frontiersin.org/article/10.3389/fmicb.2014.00429/abstract.

471 Breitburg, D. L., J. K. Craig, R. S. Fulford, K. A. Rose, W. R. Boynton, D. C. Brady, B. J. Ciotti, R. J. Diaz, K. D. 472 Friedland, J. D. Hagy, D. R. Hart, A. H. Hines, E. D. Houde, S. E. Kolesar, S. W. Nixon, J. A. Rice, D. H. Secor, $473 \&$ T. E. Targett, 2009. Nutrient enrichment and fisheries exploitation: interactive effects on estuarine living resources and their management. Hydrobiologia 629: 31-47. 
475

476

477

478

479

480

481

482

483

484

485

486

487

488

489

490

491

492

493

494

495

496

497

498

499

Cheng, X., Y. Zeng, Z. Guo, \& L. Zhu, 2014. Diffusion of nitrogen and phosphorus across the sediment-water interface and in seawater at aquaculture areas of Daya Bay, China. International Journal of Environmental Research and Public Health 11: 1557-1572.

Dahm, C. N., E. H. Trotter, \& J. R. Sedell, 1987. Role of anaerobic zones and processes in stream ecosystem productivity. Chemical Quality of Water and the Hydrologic Cycle 157-178.

Ekeroth, N., S. Blomqvist, \& P. Hall, 2016. Nutrient fluxes from reduced Baltic Sea sediment: effects of oxygenation and macrobenthos. Marine Ecology Progress Series 544: 77-92.

European Council, 2000. Directive 2000/60/EC of the European Parliament and of the Council of 23 October 2000 establishing a framework for Community action in the field of water policy. OJ L 327: 1-73.

Findlay, D., \& S. Kasian, 1987. Phytoplankton community responses to nutrient addition in Lake 226, Experimental Lakes Area, northwestern Ontario. Canadian Journal of Fisheries and Aquatic Sciences 44: s35-s46.

Foley, B., I. D. Jones, S. C. Maberly, \& B. Rippey, 2012. Long-term changes in oxygen depletion in a small temperate lake: effects of climate change and eutrophication: Oxygen depletion in a small lake. Freshwater Biology 57: $278-289$.

Forsberg, C., 1989. Importance of sediments in understanding nutrient cyclings in lakes. Hydrobiologia 176: 263277.

Fukuhara, H., \& M. Sakamoto, 1987. Enhancement of inorganic nitrogen and phosphate release from lake sediment by tubificid worms and chironomid larvae. Oikos 312-320.

Galloway, J. N., F. J. Dentener, D. G. Capone, E. W. Boyer, R. W. Howarth, S. P. Seitzinger, G. P. Asner, C. Cleveland, P. Green, E. Holland, \& others, 2004. Nitrogen cycles: past, present, and future. Biogeochemistry 70: $153-226$.

Granéli, W., 1979. The influence of Chironomus plumosus larvae on the exchange of dissolved substances between sediment and water. Hydrobiologia 66: 149-159.

Hansen, K., S. Mouridsen, \& E. Kristensen, 1998. The impact of Chironomus plumosus larvae on organic matter decay and nutrient (N, P) exchange in a shallow eutrophic lake sediment following a phytoplankton sedimentation. Hydrobiologia 364: 65-74. 
501 Hedin, L. O., J. C. von Fischer, N. E. Ostrom, B. P. Kennedy, M. G. Brown, \& G. P. Robertson, 1998. 502 Thermodynamic constraints on nitrogen transformations and other biogeochemical processes at soil-stream 503 interfaces. Ecology 79: 684-703.

504 Hölker, F., M. J. Vanni, J. J. Kuiper, C. Meile, H.-P. Grossart, P. Stief, R. Adrian, A. Lorke, O. Dellwig, A. Brand, 505 M. Hupfer, W. M. Mooij, G. Nützmann, \& J. Lewandowski, 2015. Tube-dwelling invertebrates: tiny ecosystem 506 engineers have large effects in lake ecosystems. Ecological Monographs 85: 333-351.

507 House, W. A., \& F. H. Denison, 2002. Total phosphorus content of river sediments in relationship to calcium, iron 508 and organic matter concentrations. Science of The Total Environment 282-283: 341-351.

509 Hupfer, M., S. Jordan, C. Herzog, C. Ebeling, R. Ladwig, M. Rothe, \& J. Lewandowski, 2019. Chironomid larvae 510 enhance phosphorus burial in lake sediments: Insights from long-term and short-term experiments. Science of The 511 Total Environment 663: 254-264.

512 Jensen, H., P. Kristensen, E. Jeppesen, \& A. Skytthe, 1992. Iron/phosphorus ratio in surface sediment as an 513 indicator of phosphate release from aerobic sediments in shallow lakes. Hydrobiologia 235-236: 731-743.

514 Jeppesen, E., M. Sondergaard, J. P. Jensen, K. E. Havens, O. Anneville, L. Carvalho, M. F. Coveney, R. Deneke, 515 M. T. Dokulil, B. Foy, D. Gerdeaux, S. E. Hampton, S. Hilt, K. Kangur, J. Kohler, E. H. H. R. Lammens, T. L. 516 Lauridsen, M. Manca, M. R. Miracle, B. Moss, P. Noges, G. Persson, G. Phillips, R. Portielje, S. Romo, C. L. 517 Schelske, D. Straile, I. Tatrai, E. Willen, \& M. Winder, 2005. Lake responses to reduced nutrient loading - an 518 analysis of contemporary long-term data from 35 case studies. Freshwater Biology 50: 1747-1771.

519 Klein, S., 2006. Sediment porewater exchange and solute release during ebullition. Marine Chemistry 102: 60-71.

520 Krantzberg, G., 1985. The influence of bioturbation on physical, chemical and biological parameters in aquatic 521 environments: a review. Environmental Pollution Series A, Ecological and Biological 39: 99-122.

522 Kristensen, E., 2000. Organic matter diagenesis at the oxic/anoxic interface in coastal marine sediments, with 523 emphasis on the role of burrowing animals. Hydrobiologia 426: 1-24.

524 Kristensen, E., G. Penha-Lopes, M. Delefosse, T. Valdemarsen, C. Quintana, \& G. Banta, 2012. What is 525 bioturbation? The need for a precise definition for fauna in aquatic sciences. Marine Ecology Progress Series 446: $526 \quad 285-302$. 
528 fluxes under diffusive conditions. Hydrological Processes 15: 2435-2451.

529 Leuchs, H., 1986. Die Schlaengelaktivität von Chironomuslarven (Diptera) aus flachen und tiefen Gewässern und 530 die resultierenden Wasserzirkulationen in Abhängigkeit von Temperatur und Sauerstoffangebot. Archiv für 531 Hydrobiologie 108: 281-299.

532 Lewandowski, J., \& M. Hupfer, 2005. Effect of macrozoobenthos on two-dimensional small-scale heterogeneity 533 of pore water phosphorus concentrations in lake sediments: A laboratory study. Limnology and Oceanography 50: $534 \quad 1106-1118$.

535 Lewandowski, J., C. Laskov, \& M. Hupfer, 2007. The relationship between Chironomus plumosus burrows and 536 the spatial distribution of pore-water phosphate, iron and ammonium in lake sediments. Freshwater Biology 52: $331-343$.

538 Meinikmann, K., M. Hupfer, \& J. Lewandowski, 2015. Phosphorus in groundwater discharge - A potential source 539 for lake eutrophication. Journal of Hydrology 524: 214-226.

540 Mermillod-Blondin, F., G. Fauvet, A. Chalamet, \& M. C. des Châtelliers, 2001. A comparison of two ultrasonic methods for detaching biofilms from natural substrata. International Review of Hydrobiology 86: 349-360.

542 Mermillod-Blondin, F., G. Nogaro, T. Datry, F. Malard, \& J. Gibert, 2005. Do tubificid worms influence the fate 543 of organic matter and pollutants in stormwater sediments? Environmental Pollution 134: 57-69.

544 Mermillod-Blondin, F., G. Nogaro, F. Vallier, \& J. Gibert, 2008. Laboratory study highlights the key influences 545 of stormwater sediment thickness and bioturbation by tubificid worms on dynamics of nutrients and pollutants in 546 stormwater retention systems. Chemosphere 72: 213-223.

547 Mermillod-Blondin, F., \& R. Rosenberg, 2006. Ecosystem engineering: the impact of bioturbation on 548 biogeochemical processes in marine and freshwater benthic habitats. Aquatic Sciences 68: 434-442.

549 Mermillod-Blondin, F., R. Rosenberg, F. François-Carcaillet, K. Norling, \& L. Mauclaire, 2004. Influence of 550 bioturbation by three benthic infaunal species on microbial communities and biogeochemical processes in marine 551 sediment. Aquatic Microbial Ecology 36: 271-284. 
554 Mortimer, C. H., 1941. The exchange of dissolved substances between mud and water in lakes. Journal of Ecology 555 29: $280-329$.

556 Murniati, E., D. Gross, H. Herlina, K. Hancke, \& A. Lorke, 2017. Effects of bioirrigation on the spatial and 557 temporal dynamics of oxygen above the sediment-water interface. Freshwater Science 36: 784-795.

$558 \mathrm{Ni}, \mathrm{Z}$. , \& S. Wang, 2015. Historical accumulation and environmental risk of nitrogen and phosphorus in sediments 559 of Erhai Lake, Southwest China. Ecological Engineering 79: 42-53.

560 Nogaro, G., A. M. Harris, \& A. D. Steinman, 2016. Alum application, invertebrate bioturbation, and sediment characteristics interact to affect phosphorus exchange in eutrophic ecosystems. Freshwater Science 35: 597-610.

562 Pelegri, S., \& T. H. Blackburn, 1996. Nitrogen cycling in lake sediments bioturbated by Chironomus plumosus 563 larvae, under different degrees of oxygenation. Hydrobiologia 325: 231-238.

564 Penn, M. R., M. T. Auer, S. M. Doerr, C. T. Driscoll, C. M. Brooks, \& S. W. Effler, 2000. Seasonality in 565 phosphorus release rates from the sediments of a hypereutrophic lake under a matrix of $\mathrm{pH}$ and redox conditions. 566 Canadian Journal of Fisheries and Aquatic Sciences 57: 1033-1041.

567 Pigneret, M., F. Mermillod-Blondin, L. Volatier, C. Romestaing, E. Maire, J. Adrien, L. Guillard, D. Roussel, \& 568 F. Hervant, 2016. Urban pollution of sediments: Impact on the physiology and burrowing activity of tubificid 569 worms and consequences on biogeochemical processes. Science of The Total Environment 568: 196-207.

570 Qin, L., Q. Zeng, W. Zhang, X. Li, A. D. Steinman, \& X. Du, 2016. Estimating internal P loading in a deep water 571 reservoir of northern China using three different methods. Environmental Science and Pollution Research 23: $572 \quad 18512-18523$.

573 Rapin, A., M. Grybos, M. Rabiet, B. Mourier, \& V. Deluchat, 2019. Phosphorus mobility in dam reservoir affected 574 by redox oscillations: An experimental study. Journal of Environmental Sciences 77: 250-263.

575 Saaltink, R. M., E. Honingh, S. C. Dekker, J. Griffioen, M. C. van Riel, P. F. M. Verdonschot, J. P. M. Vink, J. C. 576 Winterwerp, \& M. J. Wassen, 2018. Respiration and aeration by bioturbating Tubificidae alter biogeochemical 577 processes in aquatic sediment. Aquatic Sciences 81: 13. 
578 Schindler, D. W., 1974. Eutrophication and recovery in experimental lakes: implications for lake management. 579 Science 184: 897-899.

580 Smith, V. H., 2003. Eutrophication of freshwater and coastal marine ecosystems a global problem. Environmental 581 Science and Pollution Research 10: 126-139.

582 Søndergaard, M., J. P. Jensen, \& E. Jeppesen, 2003. Role of sediment and internal loading of phosphorus in shallow 583 lakes. Hydrobiologia 506-509: 135-145.

584 Stief, P., \& D. De Beer, 2006. Probing the microenvironment of freshwater sediment macrofauna: Implications of 585 deposit-feeding and bioirrigation for nitrogen cycling. Limnology and Oceanography 51: 2538-2548.

586 Svensson, J., \& L. Leonardson, 1996. Effects of bioturbation by tube-dwelling chironomid larvae on oxygen uptake 587 and denitrification in eutrophic lake sediments. Freshwater Biology 35: 289-300.

588 Svensson, J. M., A. Enrich-Prast, \& L. Leonardson, 2001. Nitrification and denitrification in a eutrophic lake 589 sediment bioturbated by oligochaetes. Aquatic Microbial Ecology 23: 177-186.

590 Tessenow, U., 1972. Lösungs-, diffusions-und sorptionsprozesse in der oberschicht von Seesedimenten. Arch. 591 Hydrobiol. Suppl 38: 353-398.

592 US EPA, 1991. Methods for measuring the acute toxicity of effluents and receiving waters to freshwater and 593 marine organisms. EPA/600/4-90/027.

594 Vitousek, P. M., J. D. Aber, R. W. Howarth, G. E. Likens, P. A. Matson, D. W. Schindler, W. H. Schlesinger, \& 595 D. G. Tilman, 1997. Human alteration of the global nitrogen cycle: sources and consequences. Ecological 596 applications 7: 737-750.

597 Vörösmarty, C. J., M. Meybeck, B. Fekete, K. Sharma, P. Green, \& J. P. M. Syvitski, 2003. Anthropogenic 598 sediment retention: major global impact from registered river impoundments. Global and Planetary Change 39: $599 \quad 169-190$.

600 Wetzel, R. G., 2001a. The phosphorus cycle limnology: lake and river ecosystems. Academic Press, San Diego: $601239-288$.

602 Wetzel, R. G., 2001b. Oxygen limnology: lake and river ecosystems. Academic Press, San Diego: $239-288$. 
603 Wetzel, R. G., 2001c. The nitrogen cycle limnology: lake and river ecosystems. Academic Press, San Diego: 205-

604

605

606

607

608

609

610

611

612

613

614

615

616

617

618

619

620

621

622

624

625

626

627

628 237.

Wood, L. W., 1975. Role of oligochaetes in the circulation of water and solutes across the mud-water interface. SIL Proceedings, 1922-2010 19: 1530-1533.

Wu, Z., Y. Liu, Z. Liang, S. Wu, \& H. Guo, 2017. Internal cycling, not external loading, decides the nutrient limitation in eutrophic lake: A dynamic model with temporal Bayesian hierarchical inference. Water Research 116: $231-240$.

\section{List of figures}

Fig. 1 Schema of mesocosm installation with peristaltic pump, oxygen sensor and air source. Sediment and water column compartments were $10 \mathrm{~cm}$ in height, corresponding to a volume of $0.785 \mathrm{~L}$ for each compartment.

Fig. 2 Pictures from the mesocosms: (A) control treatment without fauna, (B) U-shaped tubes produced by chironomid larvae on the inner wall of a mesocosm and (C) galleries produced by tubificid worms on the inner wall of a mesocosm.

Fig. 3 Concentrations of $\mathrm{N}-\mathrm{NH}_{4}{ }^{+}(\mathrm{A}), \mathrm{N}_{-} \mathrm{NO}_{3}{ }^{-}$(B), $\mathrm{P}_{-} \mathrm{PO}_{4}{ }^{3-}(\mathrm{C})$, and $\mathrm{SiO}_{2}$ (D) measured in the water column of mesocosms during the course of the experiment for the three fauna treatments (mean \pm standard error, $n=3$ ).

Fig. 4 Oxygen uptake rates (fluxes from water column to sediment) measured for the three fauna treatments (mean \pm standard error, $n=3$ mesocosms). For each panel, different letters ( $a, b$ and $c$ ) show significant differences among treatments (see axis label, Tukey post hoc test, $\mathrm{p}<0.05$ ).

Fig. 5 Dynamics of $\mathrm{N}_{-} \mathrm{NH}_{4}{ }^{+}(\mathrm{A}), \mathrm{N}_{-} \mathrm{NO}_{3}{ }^{-}(\mathrm{B}), \mathrm{P}_{-} \mathrm{PO}_{4}{ }^{3-}(\mathrm{C})$, and $\mathrm{SiO}_{2}$ (D) measured in the water column during the course of the experiment for the three DO treatments (mean \pm standard error, $n=3$ ).

* Concentrations of $\mathrm{P}-\mathrm{PO}_{4}{ }^{3-}$ in the anoxia treatment at day 15 are lacking due to an analytical problem.

Fig. 6 Summary of the main influence of fauna bioturbation processes on water fluxes and associated nutrient fluxes: (A) burrow construction and ventilation by Chironomus plumosus during the first week and (B) during the second week. The arrows from the water to the sediment compartment represent the fluxes of water and DO (larger arrow means larger fluxes). Arrows from the sediment to the water compartment show the release of nutrients. 
629 Fig. 7 Summary of the main influence of DO conditions in the water column on nutrient fluxes (A) oxic 630 conditions and (B) anoxic conditions.

631 
632 Fig. 1 Schema of mesocosm installation with peristaltic pump, oxygen sensor and air source. Sediment and water 633 column compartments were $10 \mathrm{~cm}$ in height, corresponding to a volume of $0.785 \mathrm{~L}$ for each compartment 634

635

Peristaltic pump

$\mathrm{O}_{2}$ sensor

636 
637 Fig. 2 Pictures from the mesocosms: (A) control treatment without fauna, (B) U-shaped tubes produced by

638 chironomid larvae on the inner wall of a mesocosm and (C) galleries produced by tubificid worms on the inner 639 wall of a mesocosm
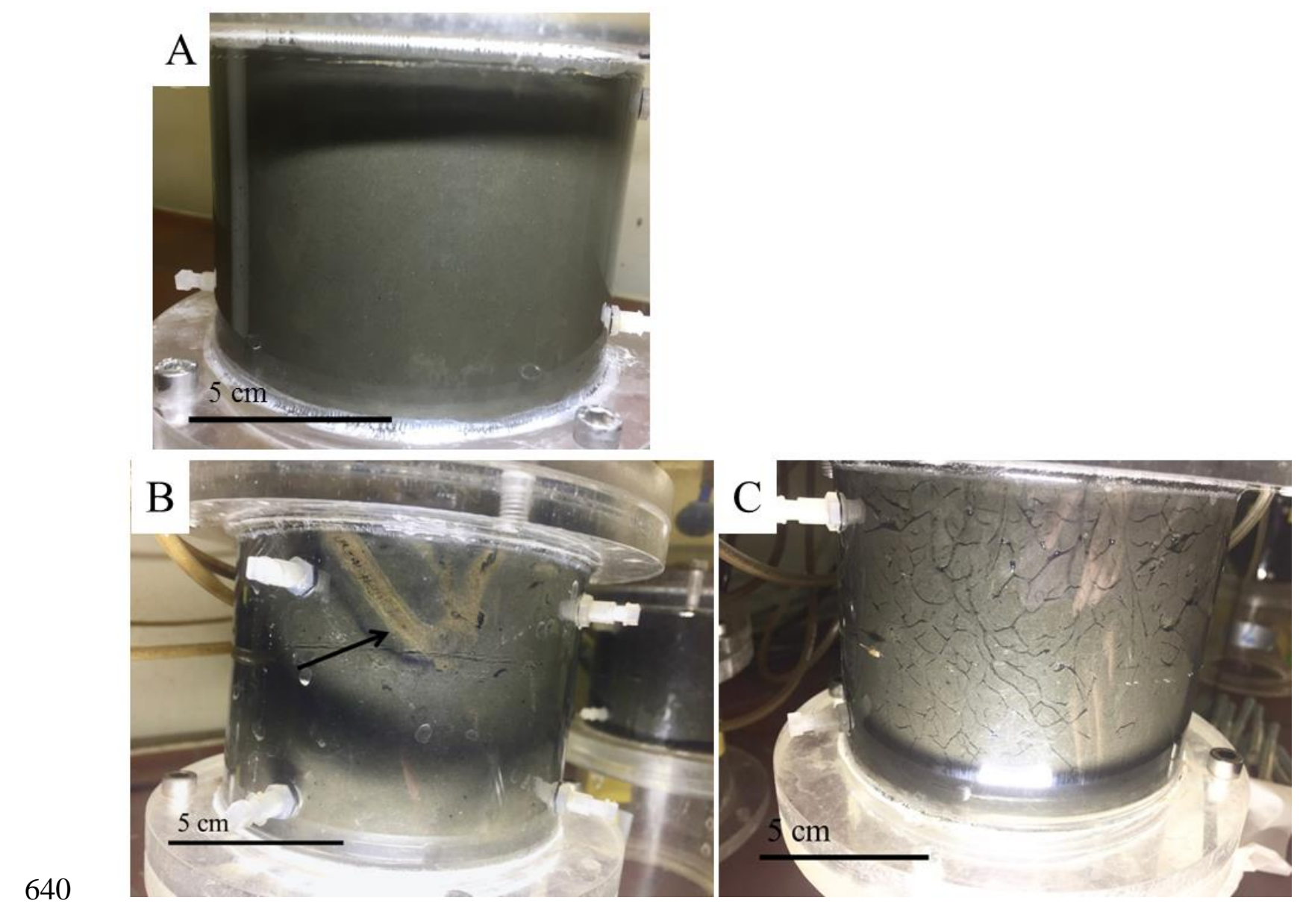

641 


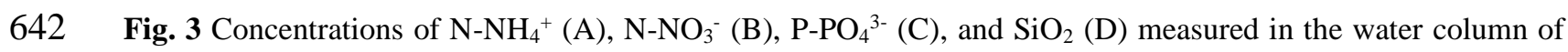
643 mesocosms during the course of the experiment for the three fauna treatments (mean \pm standard error, $\mathrm{n}=3$ ).
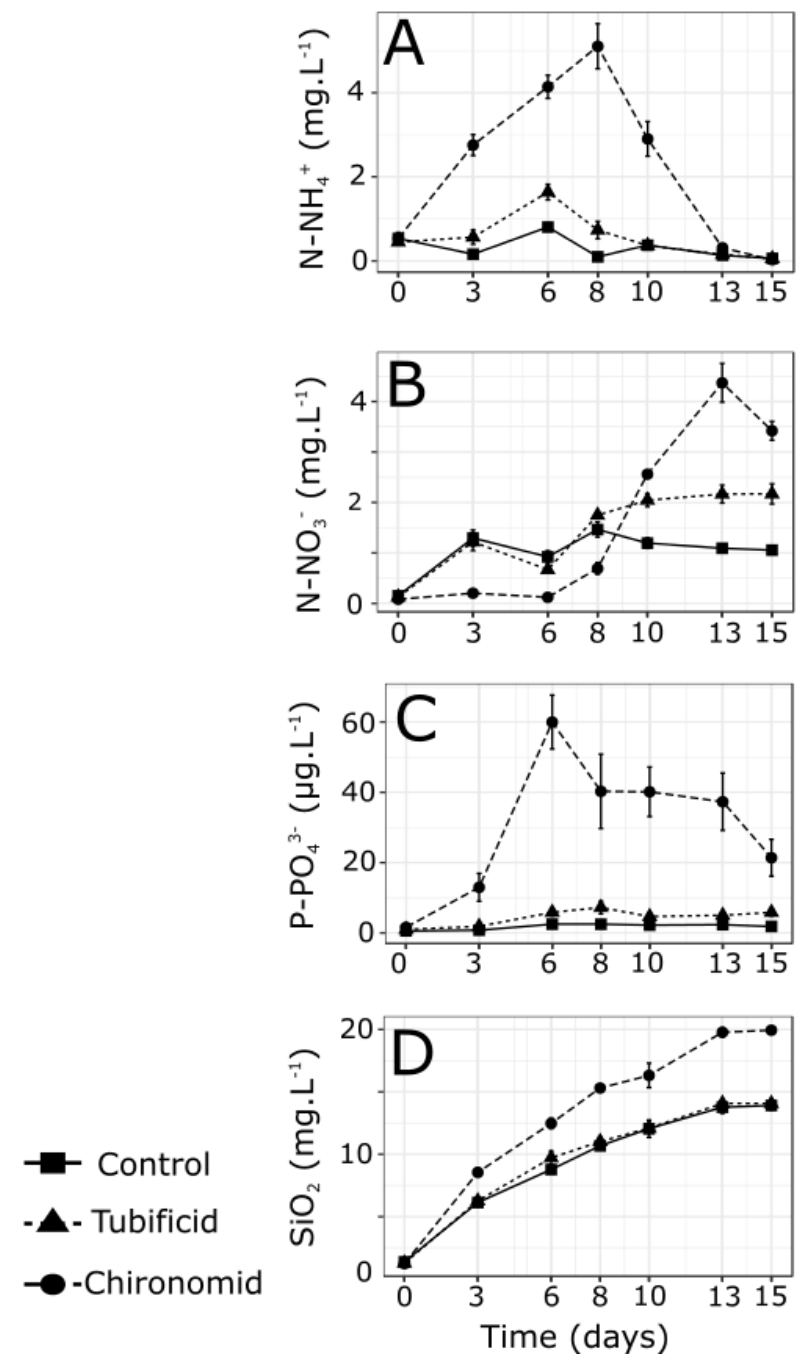

644 
645 Fig. 4 Oxygen uptake rates (fluxes from water column to sediment) measured for the three fauna treatments (mean $646 \pm$ standard error, $\mathrm{n}=3$ mesocosms). For each panel, different letters ( $\mathrm{a}, \mathrm{b}$ and $\mathrm{c}$ ) show significant differences among 647 treatments (see axis label, Tukey post hoc test, $\mathrm{p}<0.05$ ).

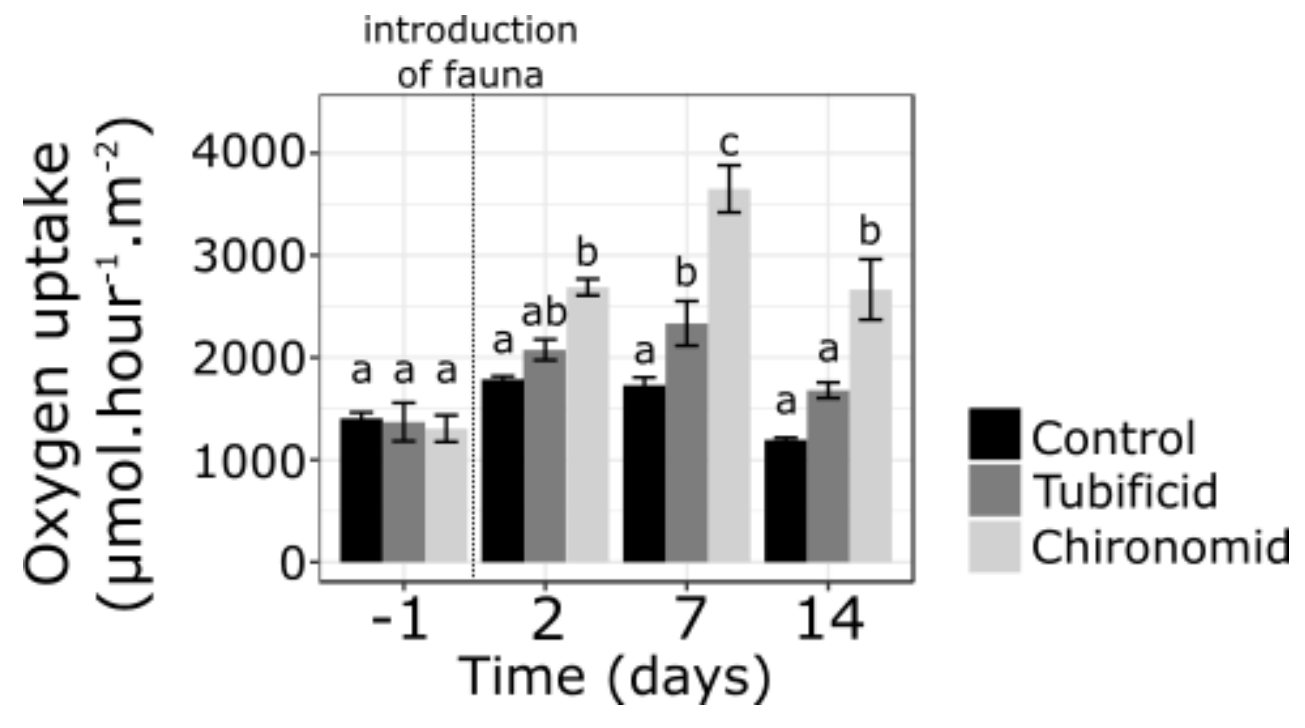

649 
650 Fig. 5 Dynamics of $\mathrm{N}-\mathrm{NH}_{4}{ }^{+}(\mathrm{A}), \mathrm{N}-\mathrm{NO}_{3}{ }^{-}(\mathrm{B}), \mathrm{P}_{-} \mathrm{PO}_{4}{ }^{3-}(\mathrm{C})$, and $\mathrm{SiO}_{2}(\mathrm{D})$ measured in the water column during the 651 course of the experiment for the three DO treatments (mean \pm standard error, $n=3$ ).
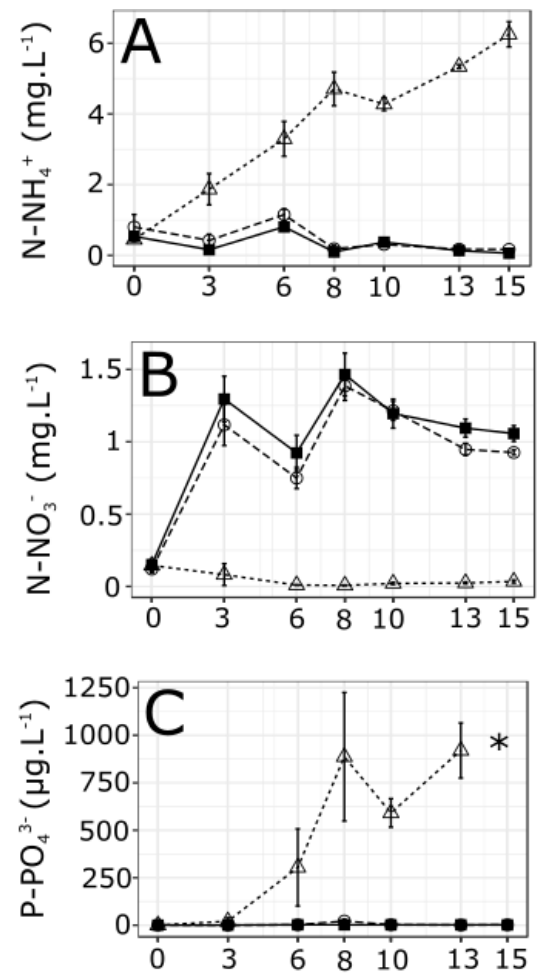

- Control $-\Theta$ - Fluctuation - $\triangle$ - Anoxia

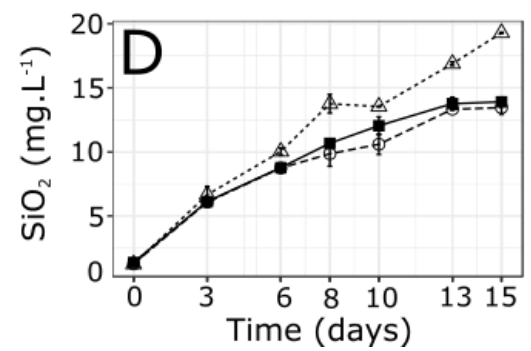


Fig. 6 Summary of the main influence of fauna bioturbation processes on water fluxes and associated nutrient fluxes: (A) burrow construction and ventilation by Chironomus plumosus during the first week and (B) during the second week. The arrows from the water to the sediment compartment represent the fluxes of water and DO (larger arrow means larger fluxes). Arrows from the sediment to the water compartment show the release of nutrients.
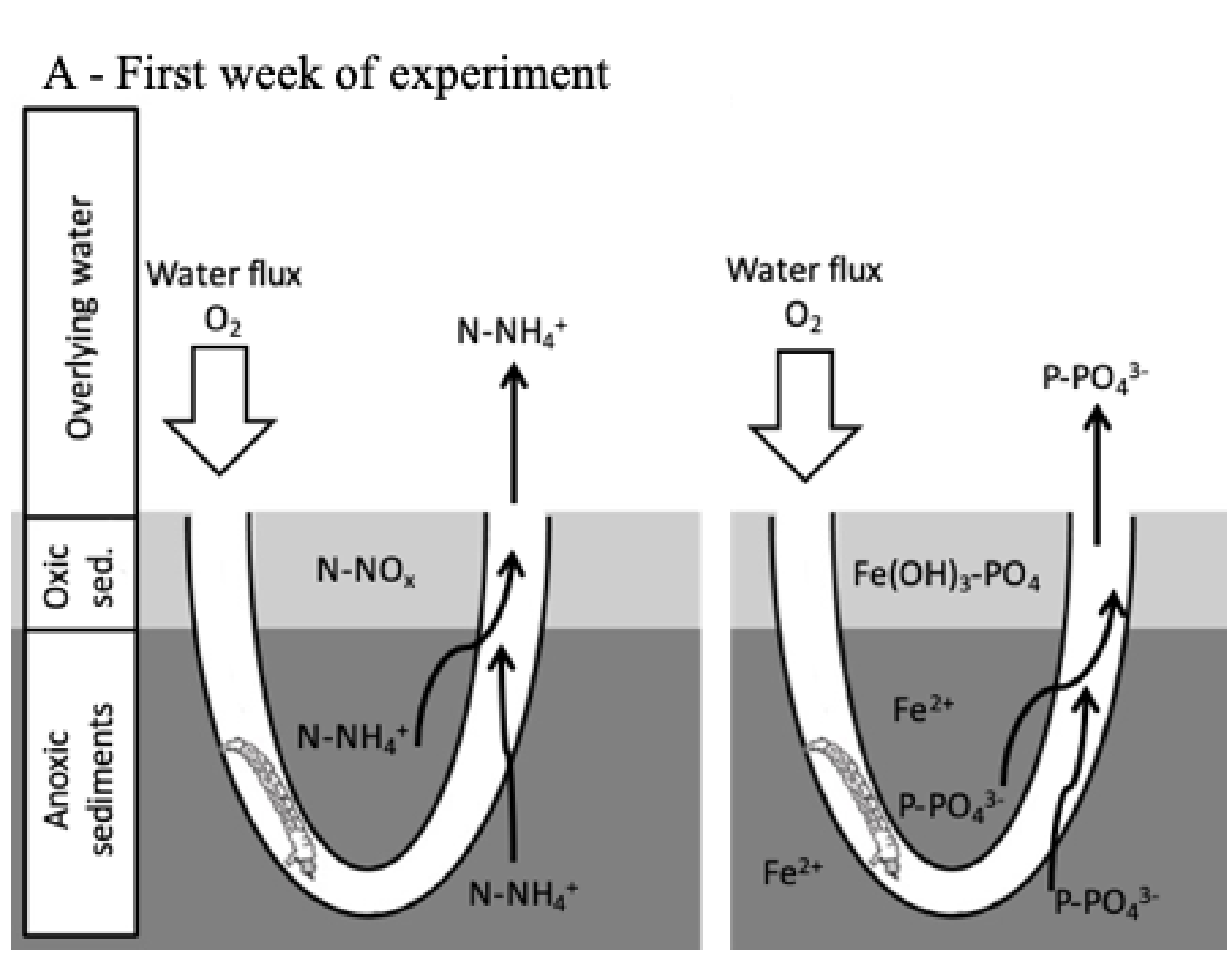

\section{B - Second week of experiment}

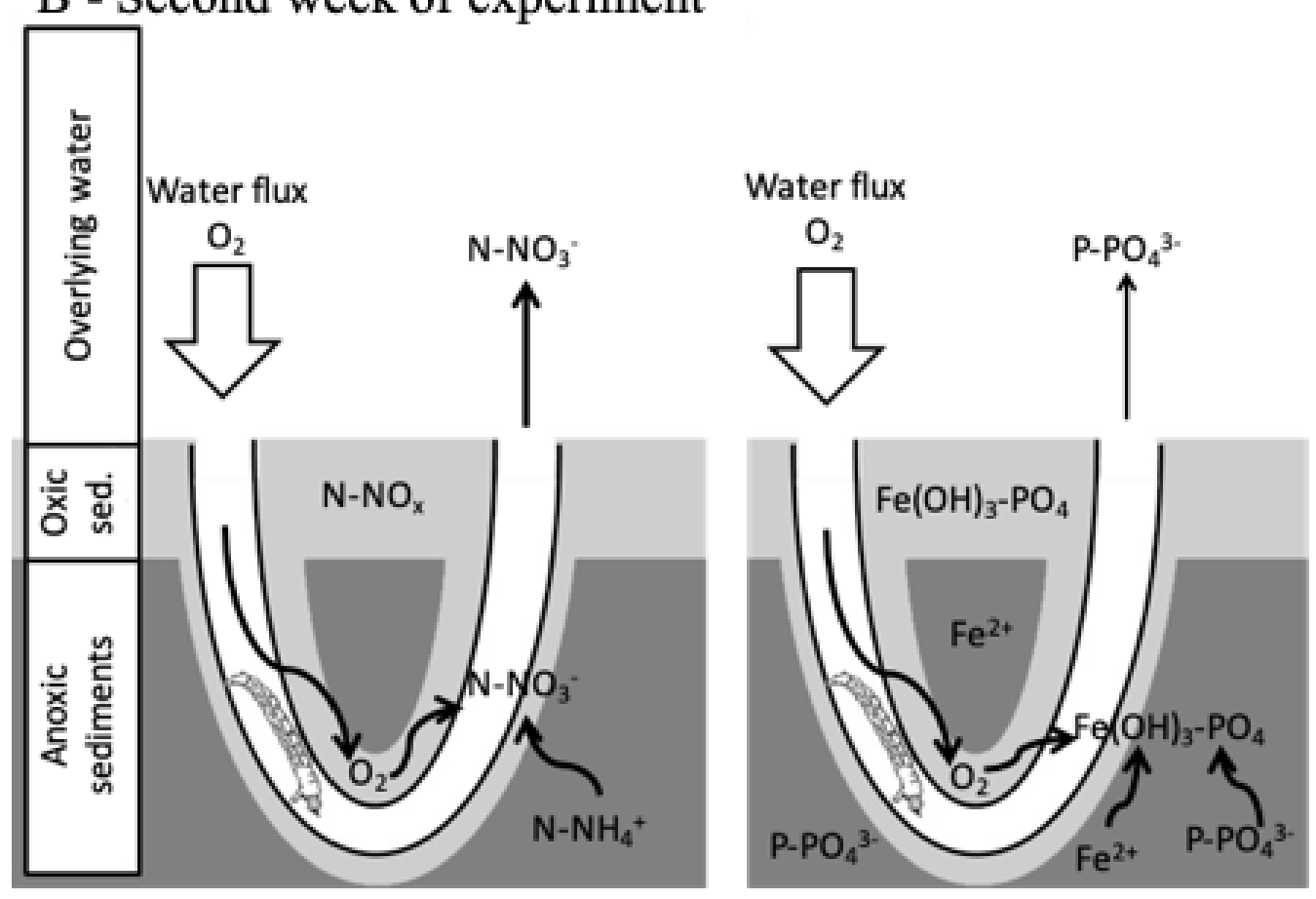


662 Fig. 7 Summary of the main influence of DO conditions in the water column on nutrient fluxes (A) oxic 663 conditions and (B) anoxic conditions.

664
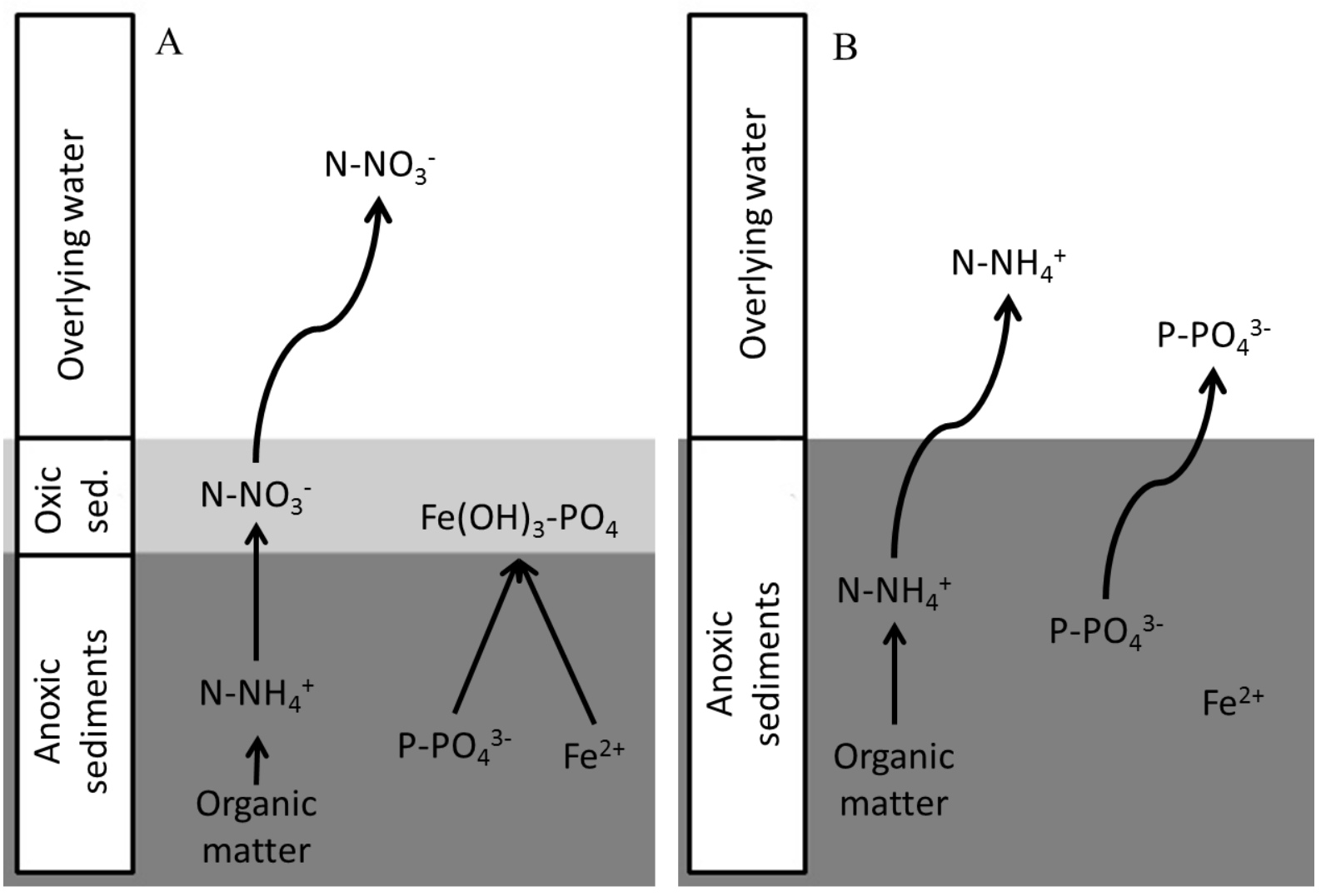

concentration of dissolved oxygen $\left(\mathrm{mg} . \mathrm{L}^{-1}\right)$ in anoxia treatment from day 2 to day 14 and (C) concentration of

668 dissolved oxygen $\left(\mathrm{mg} . \mathrm{L}^{-1}\right)$ monitored in fluctuation treatment from day 12 to day 15.
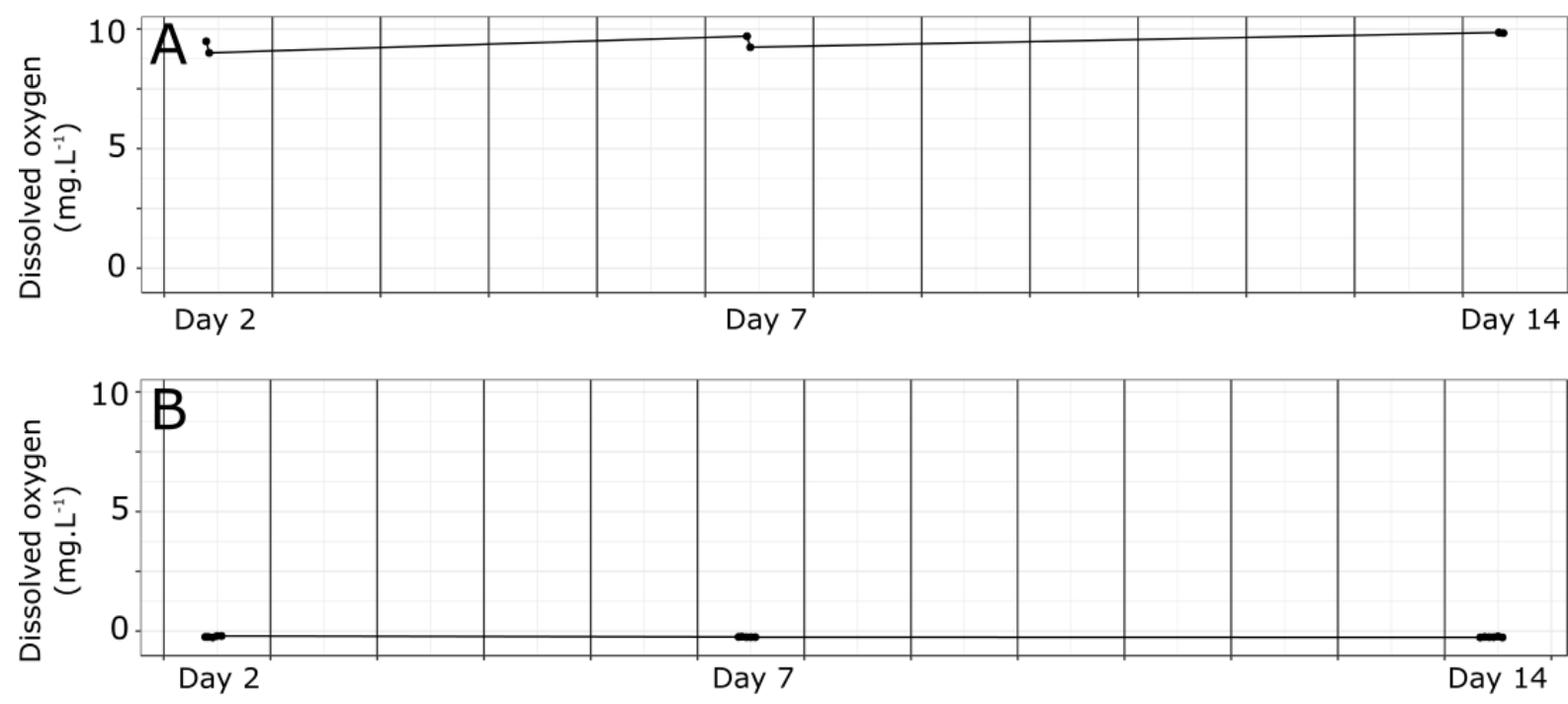

669

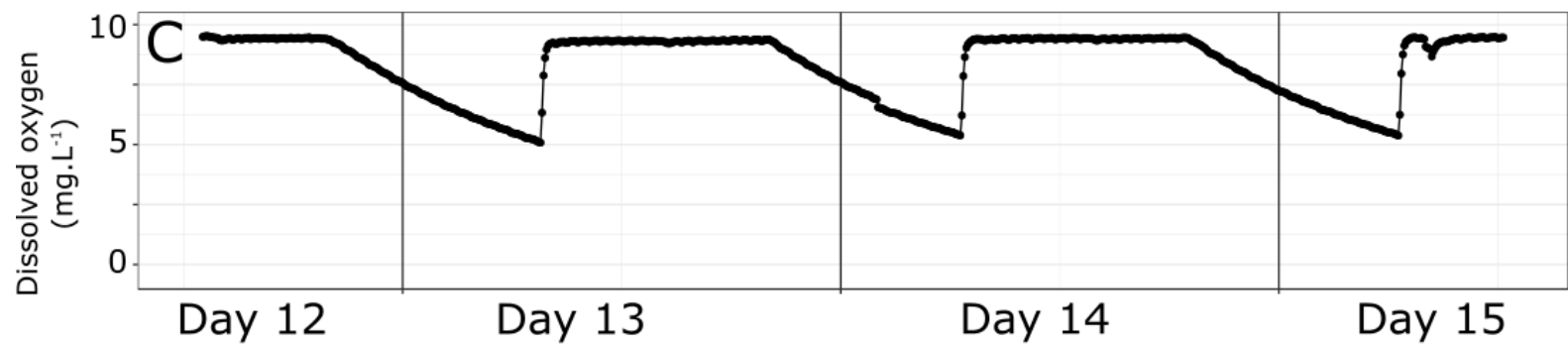

670

671

672 